\title{
Uncommon and Impact-Suspicious Geologic Phenomena across Jordan and Adjacent Areas, Arabian Plate
}

\author{
Werner Schneider ${ }^{1}$, Elias Salameh ${ }^{2}$ \\ ${ }^{1}$ Im Ziegenförth 15, D-38108, Braunschweig, Germany \\ ${ }^{2}$ Faculty of Science, University of Jordan, Amman, Jordan \\ Email: salameli@ju.edu.jo
}

Received 2 October 2014; revised 2 November 2014; accepted 1 December 2014

Copyright (C) 2014 by authors and Scientific Research Publishing Inc.

This work is licensed under the Creative Commons Attribution International License (CC BY). http://creativecommons.org/licenses/by/4.0/

(c) (i) Open Access

\section{Abstract}

For the discovery and analysis of Jebel Waqf as Suwwan (JWS) Impact Crater, Jordan pushed the authors to consequently focusing on other unusual geologic phenomena such as circular/oval structures (some of "crypto-volcanic" origin), disharmonic folding, horizontal stylolites, and a broad stripe of Sanidine-Hornfels-Facies, all of them hosted in Upper Cretaceous/Paleogene carbonate rocks exposed across Jordan and adjacent areas. Shatter cones are the most useful tools during field work in the realm of circular structures. In addition to the impact-geologic data of JWS Impact Structure hitherto available, the cooling process of melted Lower Cretaceous KurnubSandstone could be verified by microscopically identified $\mathrm{SiO}_{2}$-modifications between the melting point $\left(1714^{\circ} \mathrm{C}\right)$ and low temperatures. In comparison with the Suffield 500 tons explosion tests [20] and with the Ries Impact Crater, Germany, excavation and vaporization processes of target rocks demand drilling between Central Uplift and Inner Ring of the JWS Impact Structure ("Chert-Carbonate-Impact-Chess Game"). In a scenario: "Impacting meets Plate Tectonics", phenomena like disharmonic folding, horizontal stylolites, and an abundance of circular/oval structures of high diameter variation through northwest Jordan are discussed under aspects of gravitational gliding, effects of seismic surface waves (Love-), transpressional structures related to Jordan Rift-Tectonics, and possible impact processes of unknown number occurred on the Arabian Plate in southeastern direction with northwest-directed impulse. The so-called "Mottled Zone" of Jordan and Palestine owning a high number $(\sim 100)$ of mineral neoformations with formation temperatures up to $\sim 1120^{\circ} \mathrm{C}$ (pseudo-wollastonite $=\beta-\mathrm{CaSiO}_{3}$ ), is to be interpreted as of "Sanidine-Hornfels-Impact Facies" under ricochet conditions along an "Avenue of Ricochet-Impact-Thermo-Cataclysm". Marble-related travertines represent a low temperature facies of the impact event. The temporal projection of patterns like Rapid Climate Change (RCC), astrophysical data [Hoyle's Comet: 47], acid events in ice-cores, tektite fall, Rise and Fall of Neolithic/Bronze Age Cultures, reveals an amazing "Ensemble" of coincidences among all of these parameters since the Middle/Upper Pleistocene 
boundary throughout Holocene. Ten short Interval Cases are discussed as being "Rare Event"suspicious. Myths like the "Gilgamesch Epos" and "John's Apocalypse" surprisingly provide realistic hints on impact events comparable with modern observations and experiments, which are: approach of extraterrestrial bodies, impact cratering, earthquakes and faulting, supercyclonic whirlstorms (wildfires), effects of hot ejecta, destruction of fauna, flora, and cities, long-lasting flooding, darkness caused by ashes and dust circulating in atmosphere and stratosphere (sintwinter), and environmental pollution. Such hints were handed down in myths of $\sim 180$ ethnic peoples around the globe. "High probability Cases" focus on impact events on $\sim 9600 \mathrm{yr}$ B.P and on $\sim 6000 \mathrm{yr}$ B.P. Other "Rare Events" may have possibly occurred about $\sim 8000$ yr B.P. and on $\sim 3200$ yr. B.P. (all radiocarbon yr.cal.). Core-drilling in the pull-apart basins of the Jordan Rift System (Dead Sea, Lake Tiberias) as traps having possibly preserved volcanic and impact ejecta would be a challenging international and interdisciplinary project.

\section{Keywords}

Impact-Suspicious Phenomena, Ricochet Impact, Impact-Related $\mathrm{SiO}_{2}$-Modifications, Sanidine-Hornfels-Impact Facies, Rapid Climate Change, Holocene, Hoyle's Comet, Rise and Fall of Neolithic/Bronze Age Cultures, Coincidence of Natural and Cultural Evidence, Jordan

\section{Introduction}

After the discovery of Waqf as Suwwan Impact Crater [1]-[4], the authors were encouraged to now direct the focus on several uncommon geologic phenomena reported from the Middle East during the last 60 years. All of them cannot be interpreted with satisfaction by usual terrestrial geologic processes.

The following quotations are thought to meet the methodological and conceptional attitude relevant to this paper:

"The failure to make a clear distinction between the terms 'impossible' and 'improbable' is a fatal mistake in a science such as Geology. To relegate the 'improbable' into the realm of the 'impossible' constitutes the coward's approach on part of the modern scientist. It is caused by the realization that the acceptance of the 'Rare Event' as a viable geological agent forever removes part of Geology from the fetish of the twentieth century: rigid scientific analysis" [5].

"No matter how unorthodox the reasoning process or how unpalatable the conclusions, there is no excuse for any attempt to suppress new ideas, least of all scientists committed to the free exchange of ideas" [6].

Uncommon geologic occurrences in Jordan, Iraq, and Palestine are as follows (Figure 1):

-Circular/oval ring-like structures in Jordan and westernmost Iraq, hitherto discussed as of "crypto-volcanic" origin [7]-[9], as well as others in northwest Jordan (Figure 2, [10]).

-Disharmonic folding, horizontal stylolites, and slickensides on transverse faults hosted in chert-bearing Upper Cretaceous carbonate rocks in Jordan [11]-[13].

-Surface-related contact-metamorphic transformation of more or less bituminous Upper Cretaceous carbonate rocks to marbles of the Sanidine-Hornfels-Facies covering parts of an area about $50 \times 180$ square kilometers ranging, northwest/southeast-striking, from Central Jordan [14] to Palestine [15].

The relevant target areas are predominantly built up of Upper Cretaceous/Paleogene, partly chert-bearing limestones and marlstones. The formation ages of all phenomena fall into the period post-Eocene to early Holocene.

Widespread plateau-basalts in north Jordan, Saudi Arabia, and Syria rather marginally situated to the phenomena listed above, effused during the same time span [16]. This might challenge the question whether impact events, including Jebel Waqf as Suwwan Impact Crater, may have triggered part of magmatic and hydrothermal processes.

Furthermore, the authors do not hesitate to oppose myths of the Near and Middle East to recent scientific data, not for ascertainment, but for contemplation and valuable information.

\section{Data and Discussion}

Since carbonate rocks dominate the target area, the spectrum of impact indicators as found in silicate rocks 


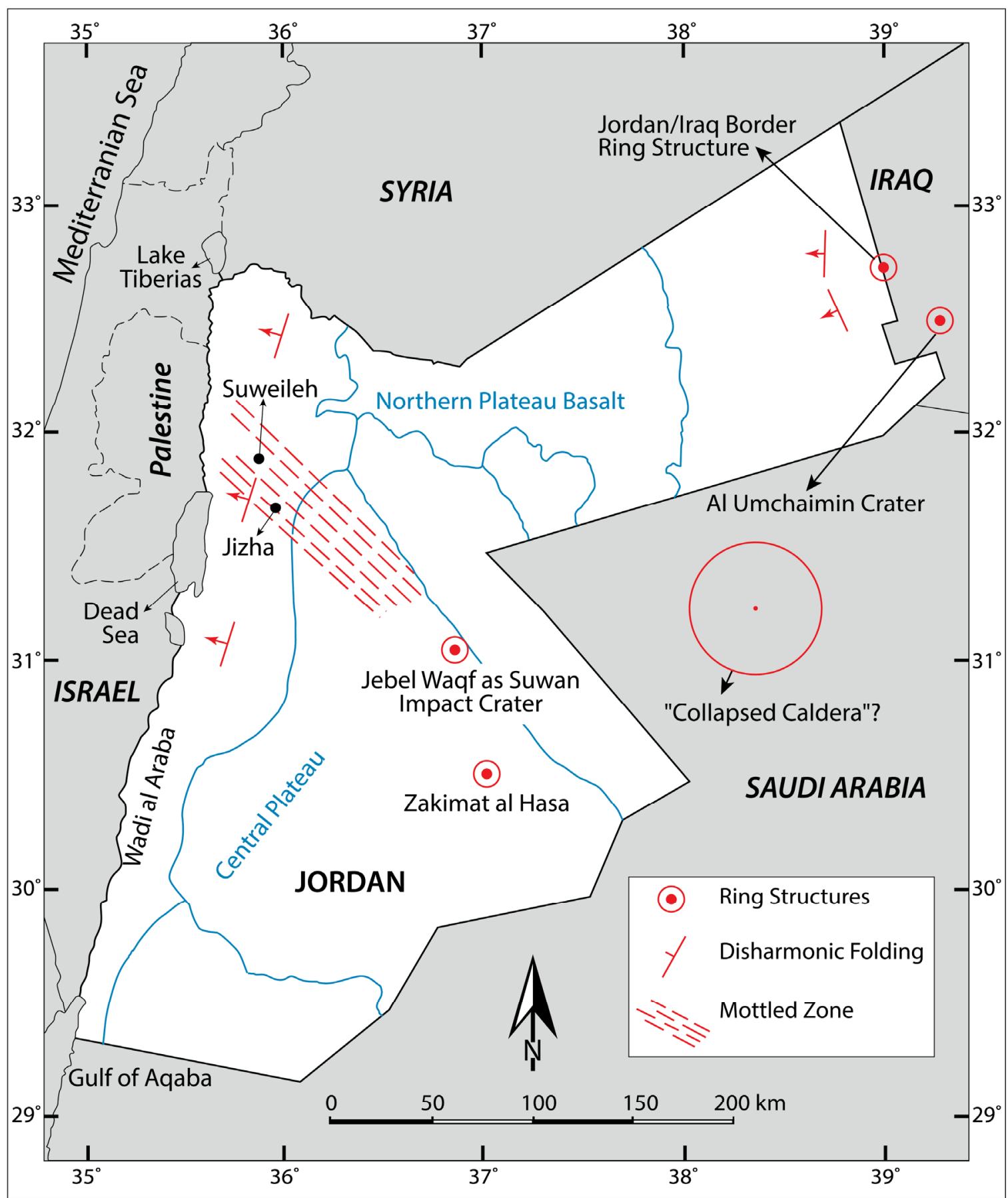

Figure 1. Location of Jebel Waqf as Suwwan Impact Structure (JWS) and other uncommon impact-suspicious geologic phenomena located across Jordan and adjacent areas. Ring Structures, "Collapsed Caldera"? [9], Axes of disharmonic folds [7] [11]-[13] [21], Stripe of Sanidine-Hornfels-Impact Facies ("Mottled Zone" = "Avenue of Ricochet-Impact-Thermo-Cataclysm") [14] [15] [26]-[29].

(Figures 3(a)-(b), [17]), cannot generally be expected in Jordan. But, in case of Jebel Waqf as Suwwan Impact Structure, parts of Lower Cretaceous sandstones of the Central Uplift underwent the impact metamorphism conditions of stage I showing planar deformation features (PDF) in quartz grains. Moreover, melting of sandstone and chert is evident [see 2.5].

However, relating to the abundance of carbonate rocks, shatter cones are the most useful tool for proving im- 


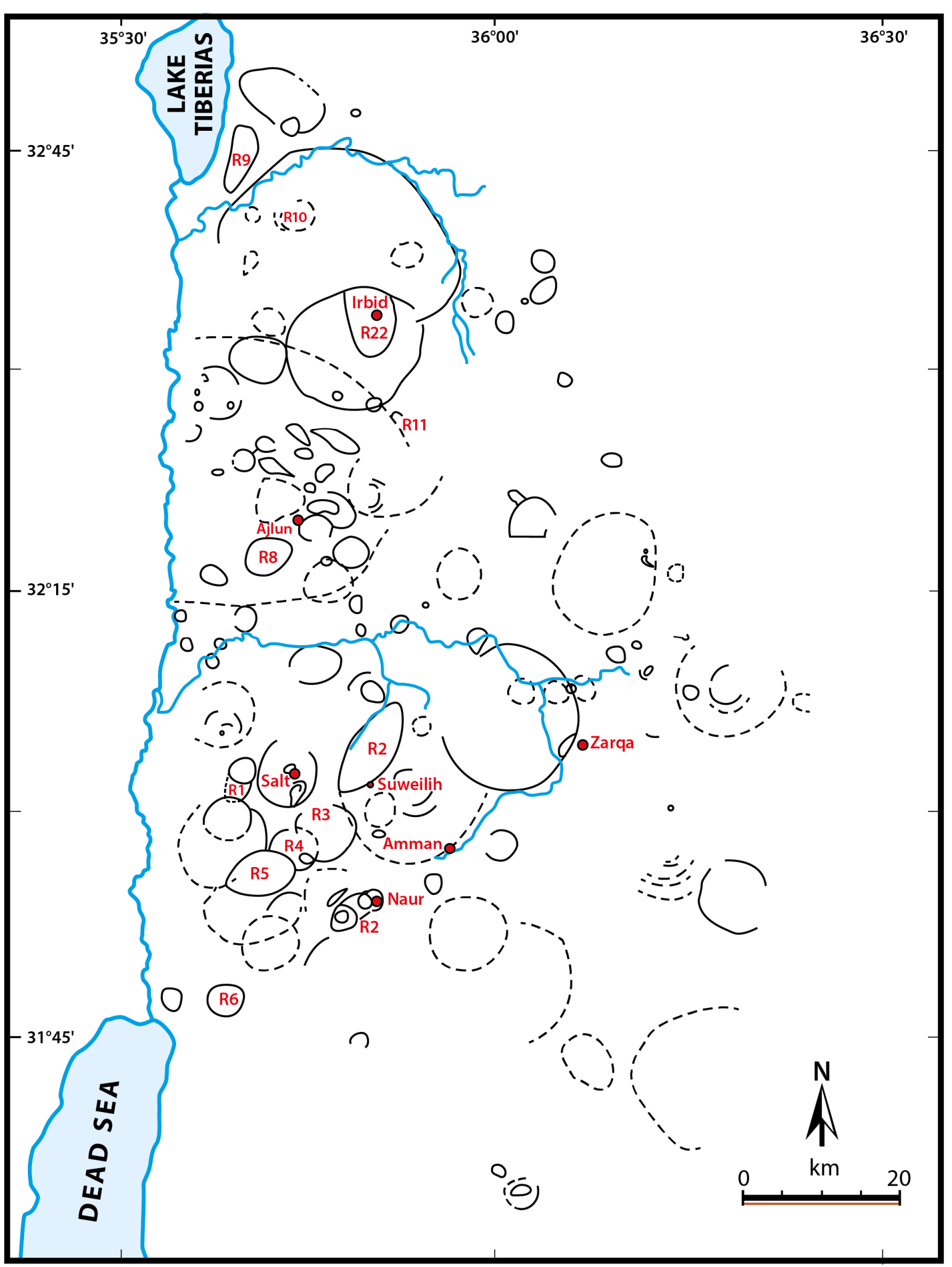

Figure 2. Ring/oval structures locallized in northwest Jordan, from Landsat-Images [10].

pact evidence in Jordan. Therefore, reaction products are to be expected from de-carbonatization (above $870^{\circ} \mathrm{C}$ ) in connection with partial melting of intercalated chert $\left(\sim 1714^{\circ} \mathrm{C}\right)$. 


\subsection{Circular/Oval Structures}

As the case of Jebel Waqf as Suwwan Structure, the following structures have also been considered by former authors as of "crypto-volcanic" origin.

\subsubsection{Structure of Zakimat Al Hasa (Figure 4, [8])}

The southwest/northeast-striking anticline of Zakimat Al Hasa is situated some 70 kilometers southwest of Jebel Waqf as Suwwan (Figure 1). It belongs to an area on the Bayir Block where a swarm of transpressional faults striking northwest, meets another west/east-striking transpressional lineament. The asymmetrical anticline measures 1 kilometer in width and 2 kilometers in length. Upper Cretaceous chert-bearing limestones running around an oval centre which is built up with Lower Cretaceous sandstones, form the uptilted rim of the structure. Its northwestern flank dips $85^{\circ}$ northwestward and is separated from barite-cemented sandstones of the centre and by a structure-parallel fault. The vertical dislocation may amount up to 120 meters. A few hundred meters away from the centre all strata show normal horizontal setting.

The structure was interpreted as of tectonic (transpressional) origin by re-activation of a Paleozoic fault-system that separated the Bayir-Block from the Jafr-Block. A "crypto-volcanic" origin could not be excluded [8].

The barite-cemented quartz grains do not show impact features (i.e., PDF). However, searching for shatter cones still makes sense.

\subsubsection{The Jordan/Iraq Border Ring Structure (Figure 5, Figure 6)}

This structure measuring 7 kilometers in diameter is located in chert-bearing Paleogene/Neogene limestones and marlstones. The Desert Highway Amman-Bagdad and the Iraqi oil pipeline cross its Central Uplift which owns a diameter of 2.5 kilometers and is surrounded by dune-covered ring-like wadis and flat hilly ridges of circular arrangement [7]. Like Jebel Waqf as Suwwan Impact Crater, the Central Uplift exhibits a positive gravity anomaly.

Northwest-striking faults run across the area. Plateau basalts and basalt dikes crop out in 70 kilometers distance west of the Ring Structure interpreted as of "crypto-volcanic" origin, too.

A modern study provides additional data of the geologic setting and remote sensing, still without any evidence of impact features [18]. Nevertheless, there is a very high probability for finding shatter cones close to the Central Uplift!

\subsubsection{The Al Umchaimin Crater, West Iraq (Figure 7)}

Located 42 kilometers southeast of the Jordan/Iraq Border Ring Structure at Wadi Shueib al Walej, the structure measures 3.3 kilometers in diameter and was also interpreted as of "crypto-volcanic" origin [9].

\subsubsection{A "Collapsed Caldera" Hosted in Quaternary Plateau Basalts (Figure 1, Figure 7)}

This huge post-magmatic structure localized in northwesternmost Saudi Arabia, measures some 60 kilometers in diameter, situated about 100 kilometers southwest of Jebel Aniza amidst widespread plateau basalts [9]. Its centre exposing a basaltic cone lies 125 - 160 meters deeper than the lava-capped hills of its rim. Radial and arcuate faults run across the structure.

The plateau basalts extend over hundreds of kilometers southeastward into Saudi Arabia and northwestward into Syria [16]. They represent one of the youngest of six effusions all ranging in age from late Miocene to postmiddle Pleistocene.

The alkali-basalts of Upper Mantle provenance were extruded along deep faults in an intra-cratonic setting of the Arabian Plate. They relate to the opening of the Red Sea and the Jordan Rift System [19].

Regarding Mitschel's "Collapsed Caldera", such large volcanic craters of alkali-basalt signature can never be found on a craton. However, volcanic craters of tens of kilometers in diameter are typical in volcanic arcs above subduction zones revealing a calc-alkali signature [19] which is not relevant on the Arabian Plate.

Therefore, if this structure was verified as a crater, the probability for a major impact would be very high, as Price [20] postulated the triggering of the Deccan Traps, India and other plateau basalts by major impacts.

The Suffield Tests ([20]) reveal the same crater inventory, namely fissures and fractures in radial and arcuate-concentric arrangement. The basaltic cone in the centre of the "Collapsed Caldera" challenges the question of magma effusion triggered by an impact. 


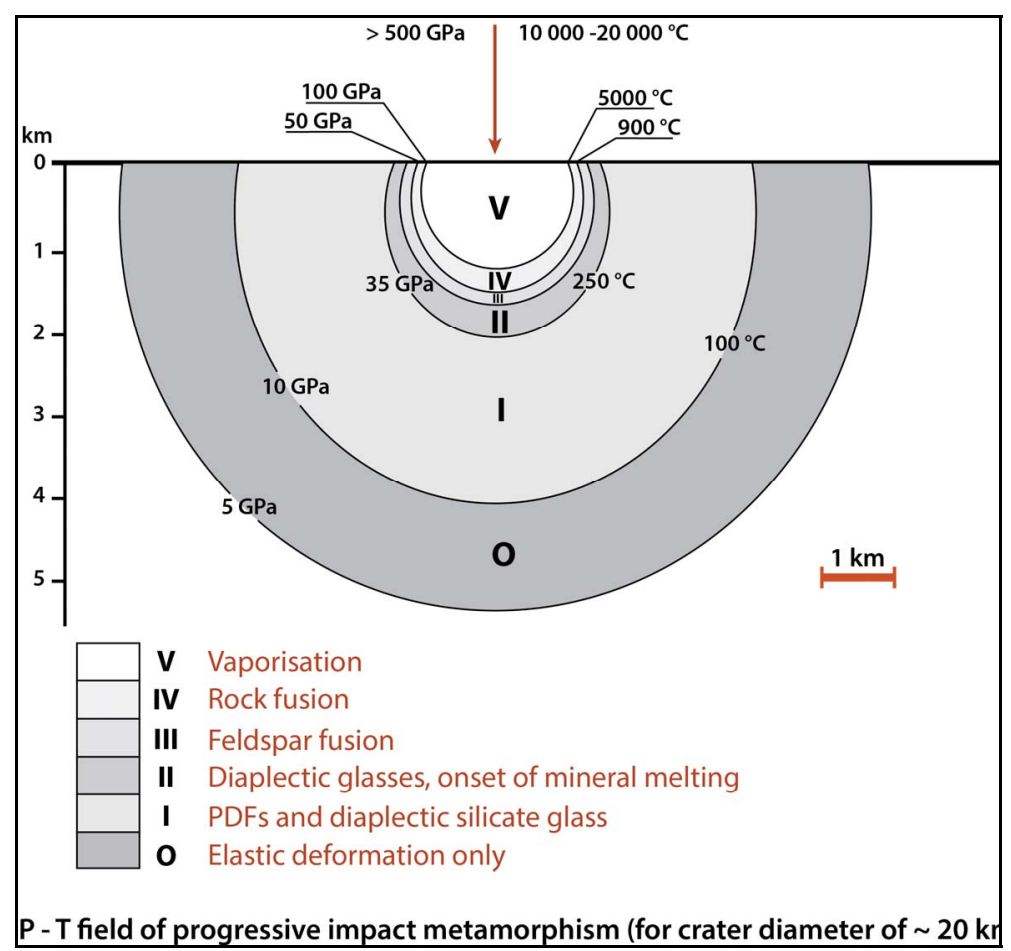

(a)

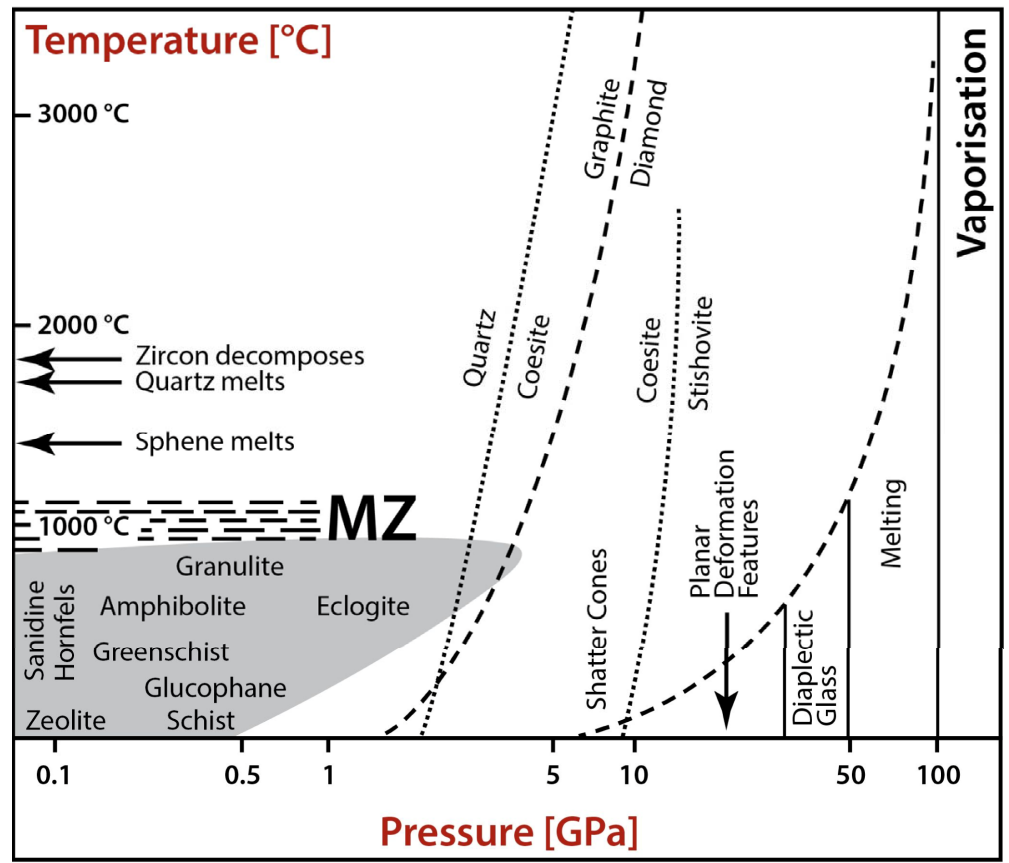

(b)

Figure 3. (a) Progressive impact metamorphism: shock pressure and temperature decrease radially outward from the impact centre. Zones $\mathrm{O}-\mathrm{V}$ are characterized by definite deformation features. Slightly modified and corrected $\left(500^{\circ} \rightarrow 5000^{\circ} \mathrm{C}^{\mathrm{x}}\right)$ from W.U. Reimold [17] relating to D. Stöffler. (b) P-T- fields of terrestrial metamorphism (dark field) and impact metamorphism. Note the additional field of the "Mottled Zone" MZ (see 2.3) and the features of shatter cones, melting and vaporization relevant in this paper. From W.U. Reimold [17] relating to B.M. French. 


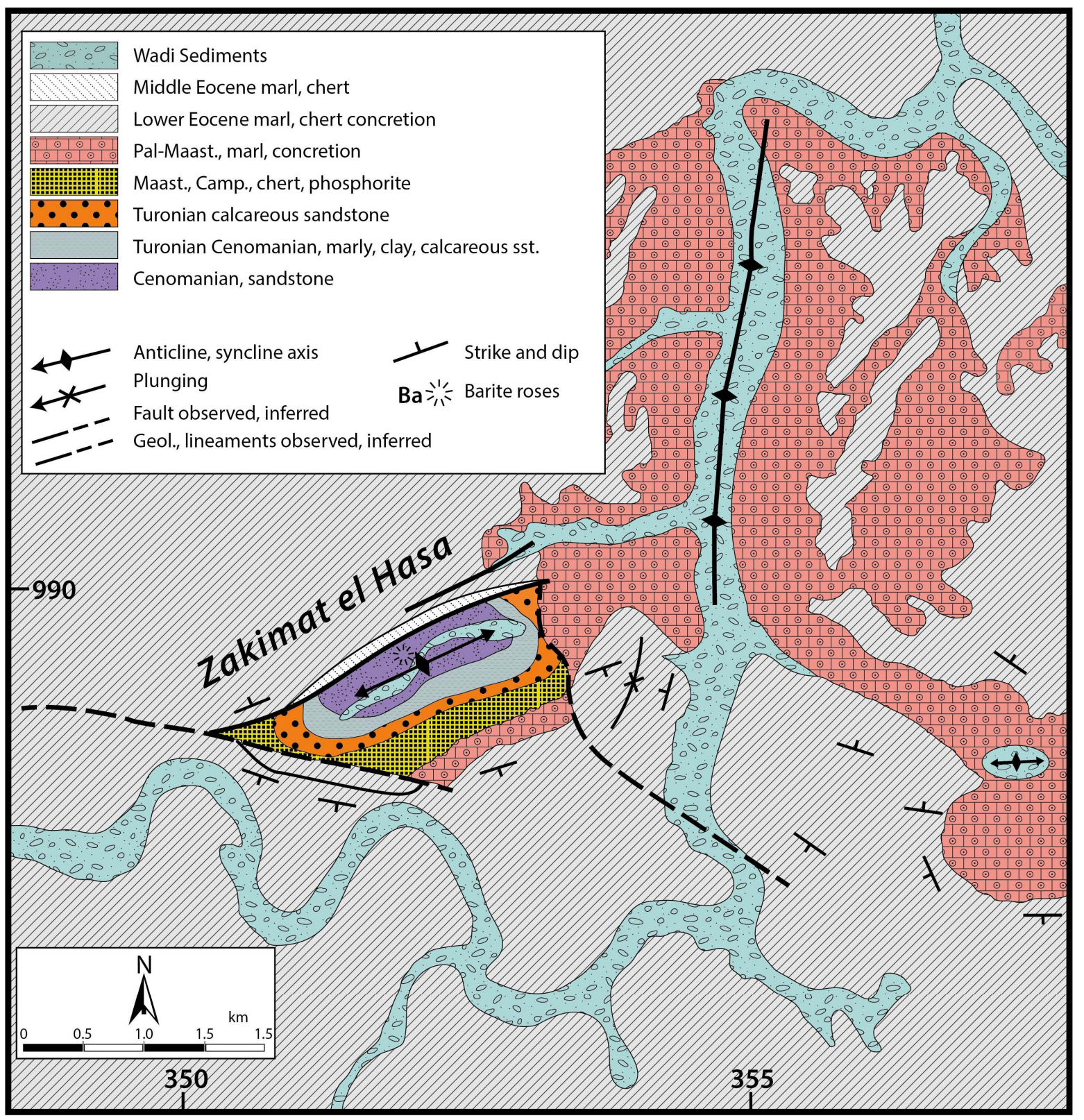

Figure 4. The oval structure of Zakimat Al Hasa, Central Jordan (after Heimbach [8]).

\subsubsection{Other Circular/Oval Structures from Landsat-Images in Northwest Jordan (Figure 2)}

According to Landsat-Images across northwest Jordan, an abundance of circular and oval structures $(\sim 100)$ are densely distributed in mainly Upper Cretaceous carbonate rocks [10]. Their diameters range from tens of meters up to 35 kilometers. Oval structures own uniformly striking axes (northeast/southwest to north-northeast/ south-southwest). Some of the ring-like structures as Baq'a (R1) and Na'ur depressions (R2) expose Lower Cretaceous sandstones in their centre, surrounded by a rim of Upper Cretaceous limestones (Figure 2).

Several northwest-verging local fold-belts definately indicate a uniform compressional stress vector directed from east/southeast to west/northwest direction. Certainly, many of the smaller circular structures are sinkholes generated by Karst processes. However, the majority of the oval structures do not seem related to Jordan Rift tectonics that stands for left side transform-faulting [10].

Consequently, since there only exists one main stress vector directed towards west-northwest/northwest, seismic surface waves (Raleigh-Love-) have to be considered as of having caused the deformation of the oval 


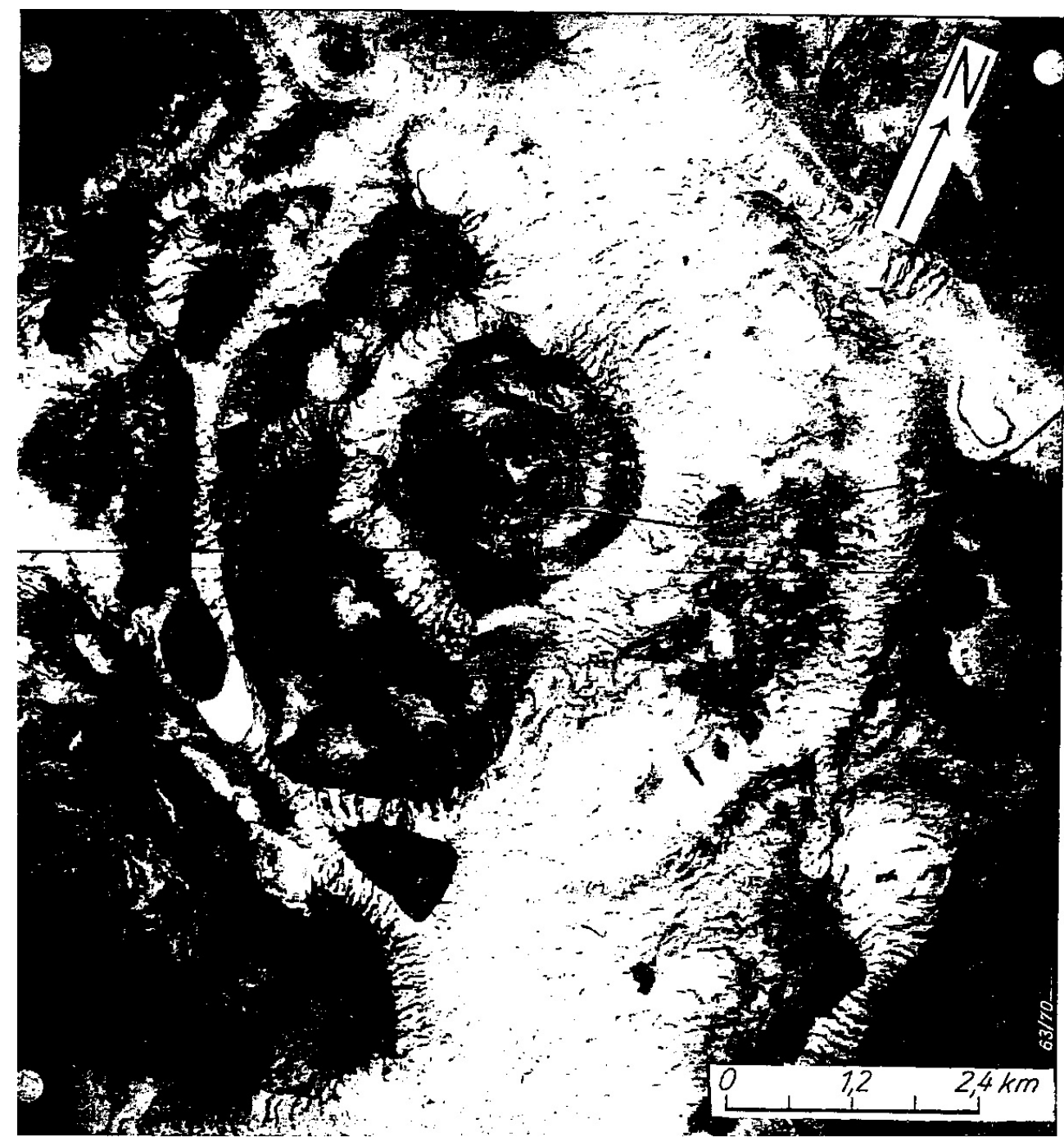

Figure 5. Aerial photograph of the Jordan/Iraq Border Ring Structure, hunting technical services, London 1956, see [7]. Dark areas: more or less exposed in-situ carbonate rocks, bright areas: sandcovered.

structures in northwest Jordan. This is to be more analyzed in the following Ch. 2.2, where the same deformation patterns are relevant for several other uncommon phenomena.

The Suffield Tests, explosive TNT experiments (500 tons), conducted in Alberta, Canada (Snowball Crater: 87 meters in diameter) evidenced that the maximum principle stress during explosion acted radially generating series of peripheral folds of small wave length and amplitude [20]. So the stress worked normally to the fold axes. It can be inferred that fold development is controlled by the anisotropy of sedimentary layers.

Related to northwest Jordan, the deformation of former circular structures to such of oval shape, in combination with high gliding mobility of overlying competent limestones moving over clay-bearing incompetent marlstones, is convincing in this area (see more cratering mechanic details in Ch. 2.2). The abundance of circular structures being not of karst origin, challenges their mapping by shatter cones.

\subsection{Uncommon Structural Features Hosted in Upper Cretaceous/Tertiary Chert-Bearing Carbonate Rocks of Central and North Jordan (Figure 1)}

In the northwestern part of Jordan, between Karak and Irbid, the Upper Cretaceous Silicified Limestone Unit exhibits disharmonic folding of a 30-meter-thick sequence of alternating cherts and carbonate rocks (Figure 8). 


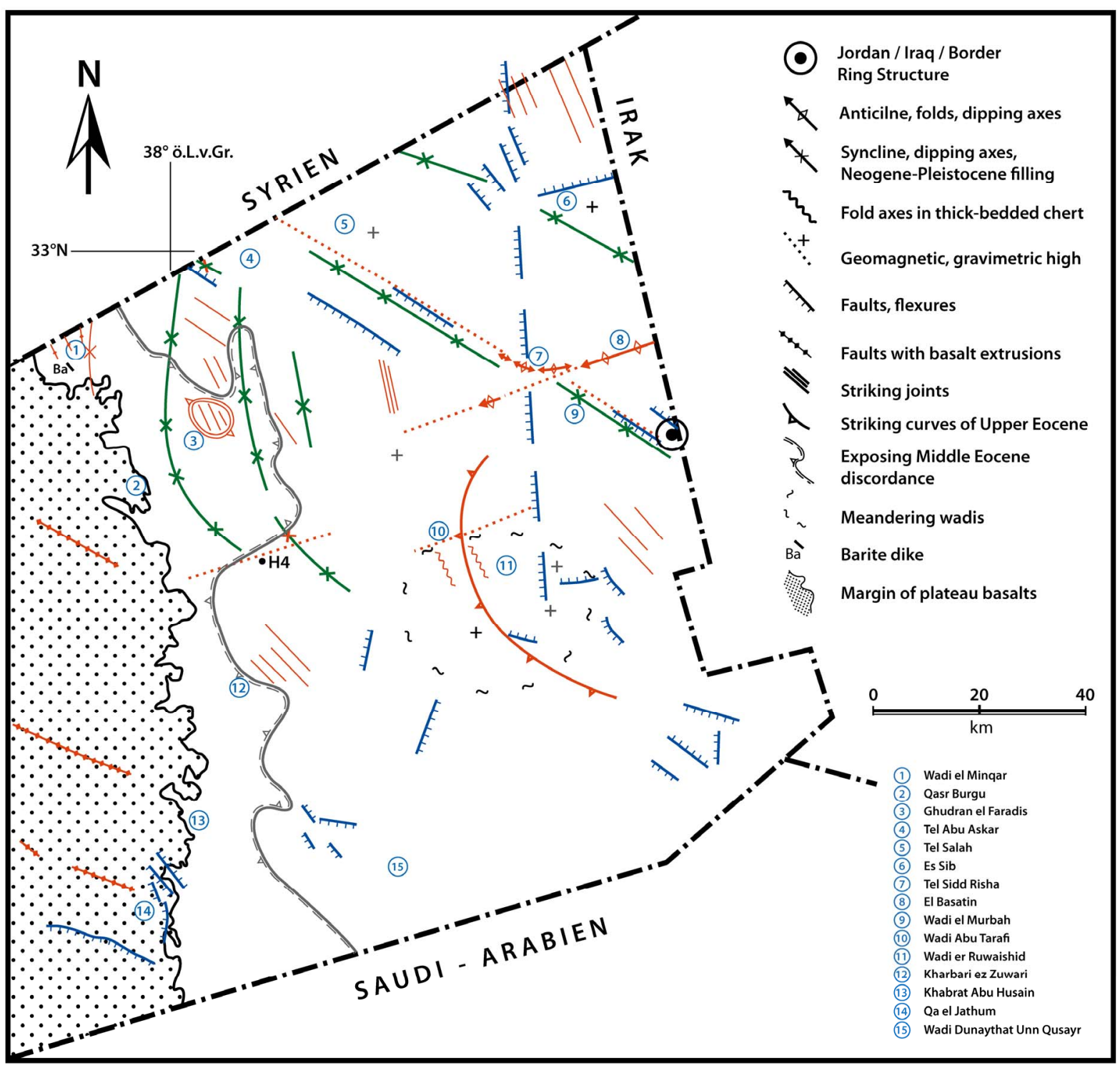

Figure 6. Arcuate structures and disharmonic folding at Tarifi and Ruwaishid located westward and related to the Jordan/Iraq Border Ring Structure [7].

The folds spontaneously appear north of Karak, near Madaba, northwest of Amman, and south of Irbid [11] [13]. They reveal amplitudes of five to ten meters and wave lengths of up to some hundred meters. The foldaxes almost strike constantly at $15^{\circ}-20^{\circ}$ northeast. The folded sequence is underlain with unaffected 20 -meter thick marlstones and overlain by 50-meter-thick marlstones plus 400 -meter-thick massive Maastrichtian and Eocene limestones. The chert layers of the folded sequence are more or less brecciated. The fold-axes do not have any relationship with former faults. Some of the folds verge towards west-northwest.

Adequate disharmonic folding does also appear in early Tertiary chert layers radial-symmetrically and concentrically related to the Jordan/Iraq Border Ring Structure located about 45 kilometers northeast from the occurrences in the Wadi Abu Tarifi and Wadi er Ruwaishid (Figure 6, [7]). Similar phenomena are also described from Senonian cherts in Israel [21].

Such phenomena were interpreted as of synsedimentary gliding or as of gravitational gliding from the uplifted Trans-Jordanian Block respectively from the Arabian Swell [22].

According to Sander [23], there is evidence that the incompetent folded chert-bearing sequence was deformed in between two "vice jaws", namely the underlying massive Turonian carbonate rocks and the thick overlying 


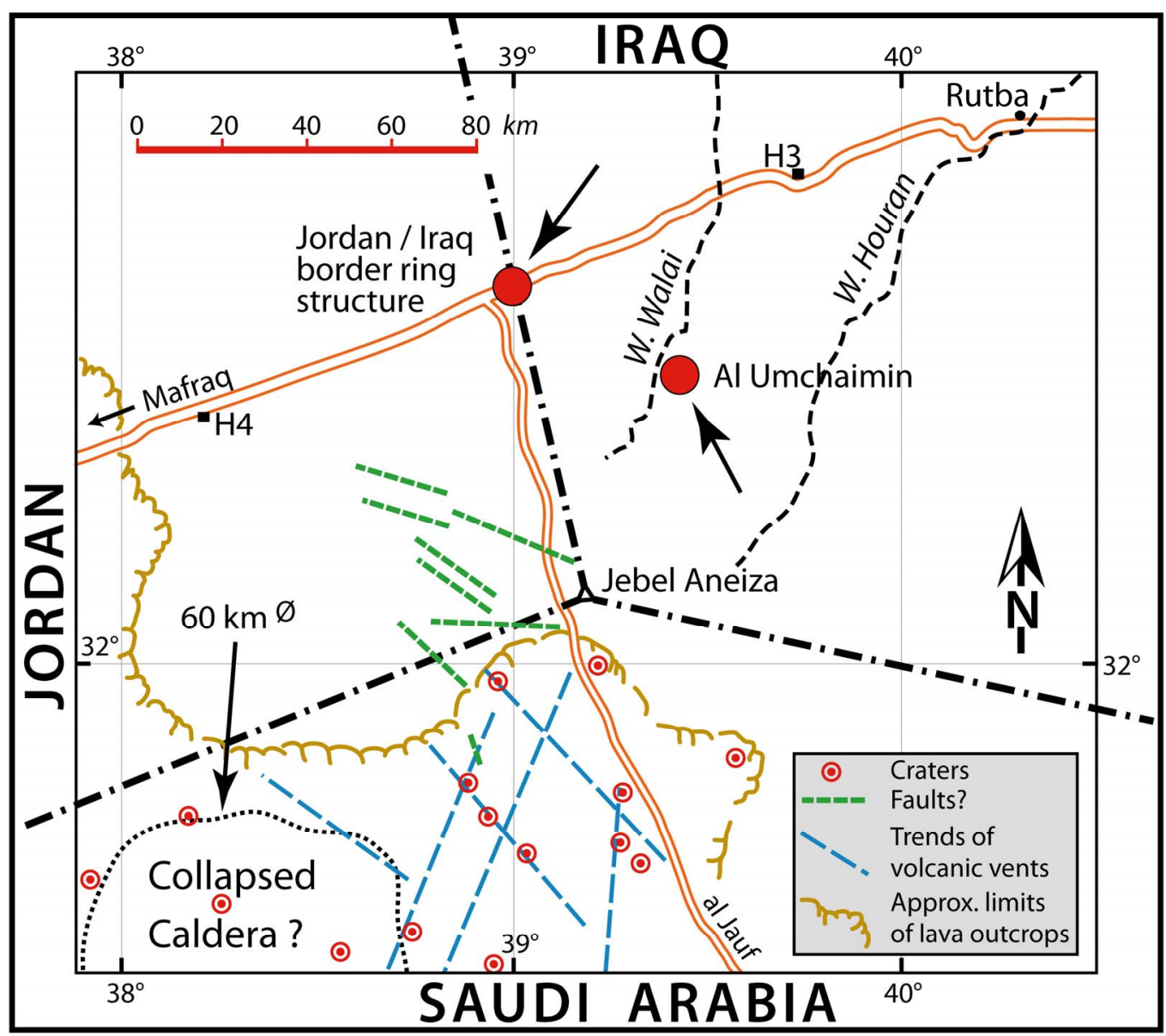

Figure 7. Location of the al umchaimin crater at wadi sha'ib al walej, west Iraq, and the so-called "Collapsed Caldera"? some 100 kilometers southwest of Jebel Uniza, northwesternmost Saudi Arabia [9].

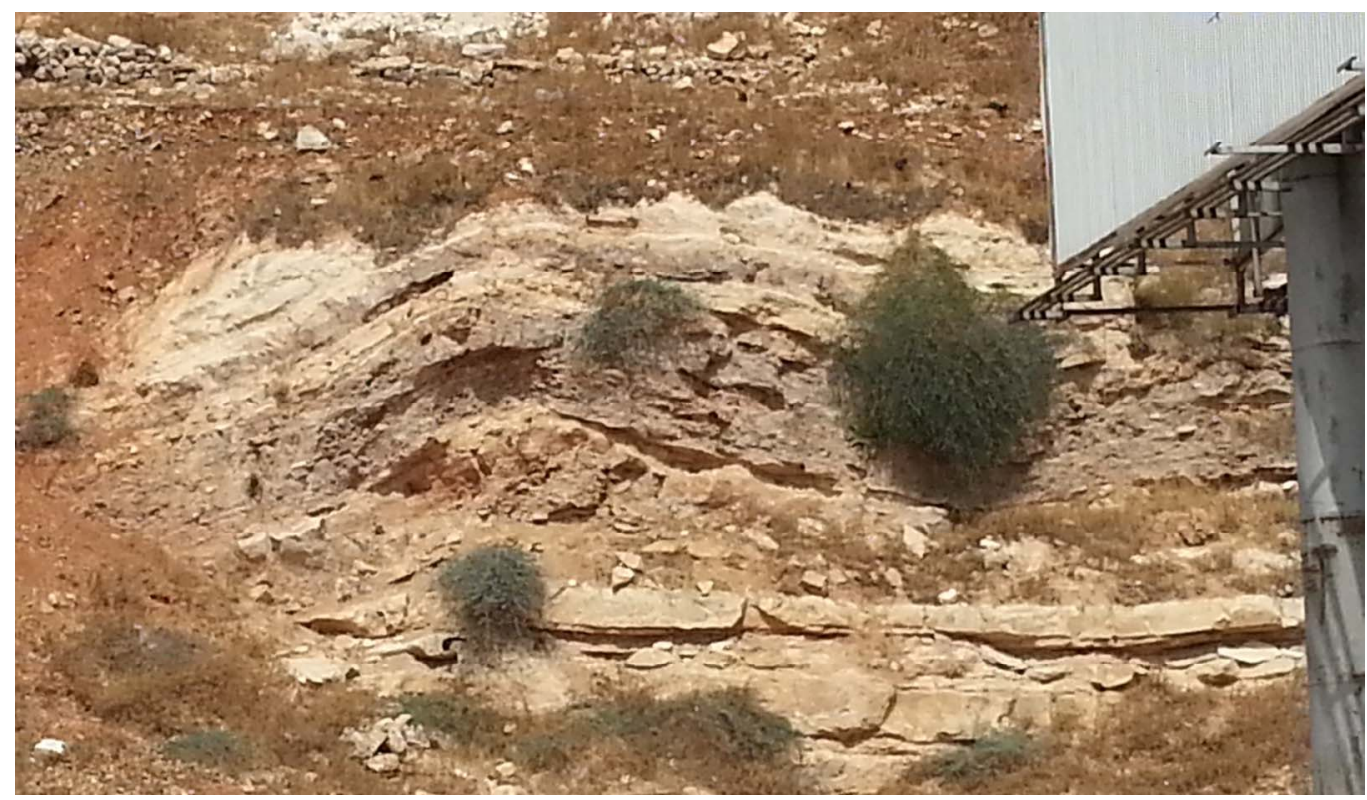

Figure 8. Northwest-verging disharmonic folding within Upper Cretaceous silicified limestone near Karak. Note thin intercalated chert layers. 
competent Maastrichtian/Tertiary limestones have moved west-northwestward on the incompetent folded sequence (Figure 9, Figure 10).

We follow Wiesemann's concept [22] of gravitational gliding and combine it with the effect of seismic waves as surface waves (Raleigh and Love waves), possibly initiated by major impacts having occurred further eastsoutheast [24].

In the same area of northwest Jordan, as indicated by disharmonic folding, horizontal stylolites (Figure 11) and slickensides (Figure 12) occur in the Upper Cretaceous Nodular Limestone [12] [13]. Two maxima of striking $\left(135^{\circ}, 170^{\circ}\right)$ were encountered on joints and fractures. The discussed paleostress was related to Jordan Rift tectonics.

All features hitherto discussed, may be explained by seismic surface waves (Figure 10). In order to better understand the theoretical aspects of the impact process with special regard to surface waves, a view on the Ries Crater, Germany, appears helpful [25].

Raleigh waves occur in the case of strong earthquakes respectively as major impacts. They immediately start after the impact as elastic transversal surface waves from the crater rim by ring-like extension. On top of the waves a foreword movement initiates a gliding process. The velocity of the Raleigh wave ( $\sim 50 \mathrm{~meter} / \mathrm{s})$ only

WNW

ESE

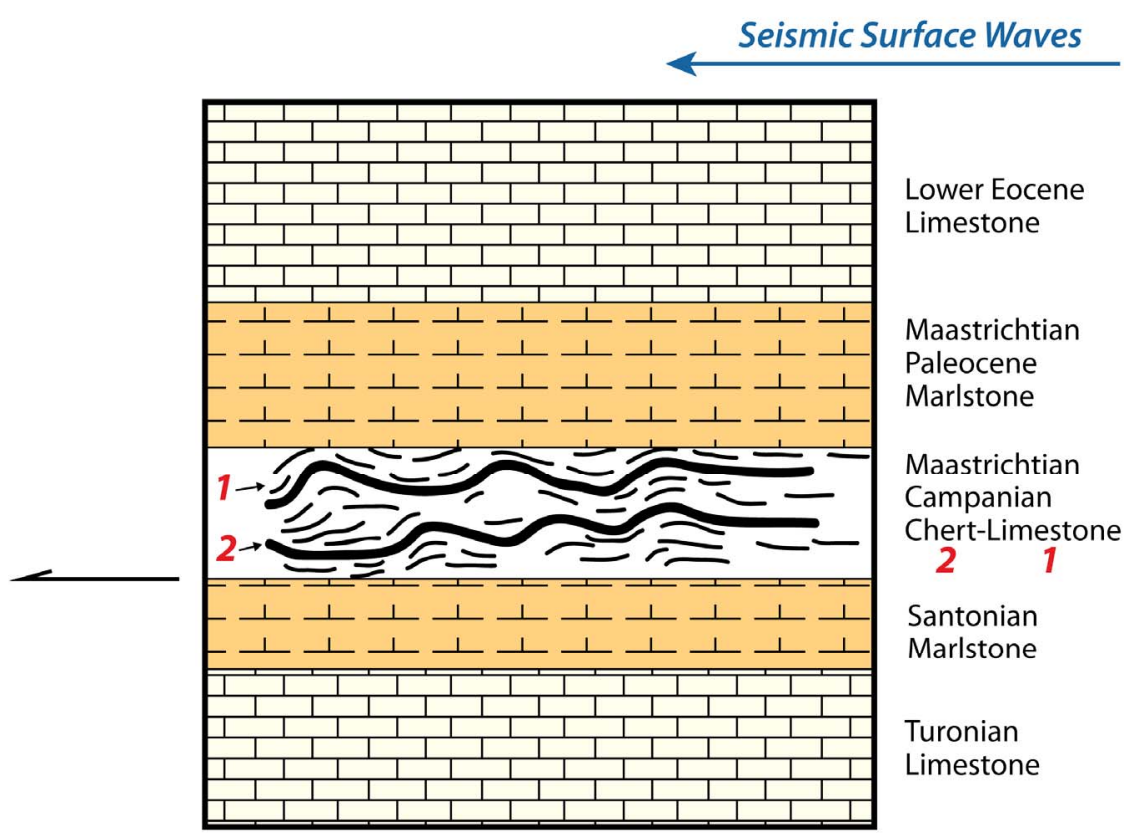

Figure 9. Schematic profile of chert-bearing Upper Cretaceous carbonate rocks affected by seismic surface waves (Love waves) [23]-[25].

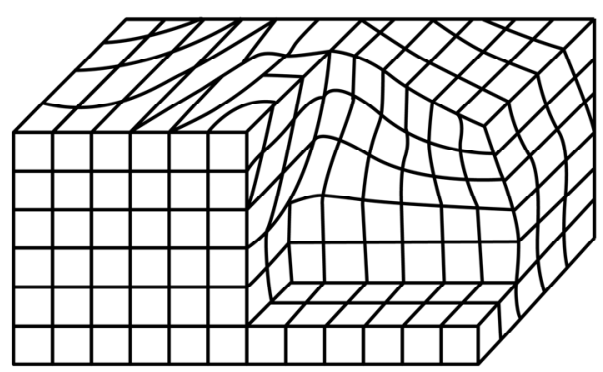

(a)

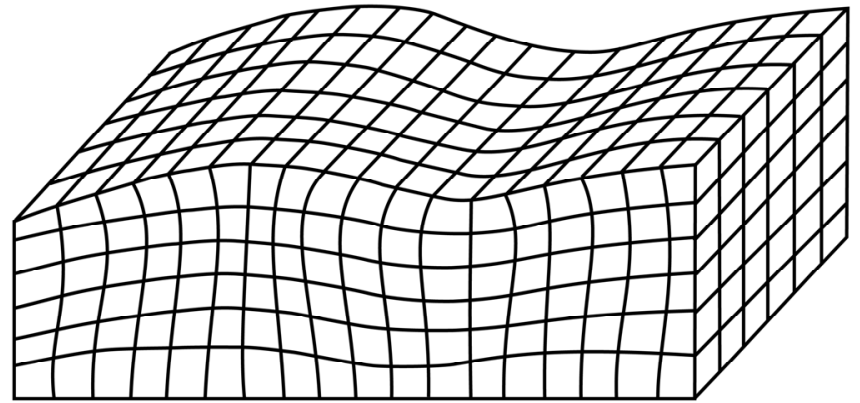

(b)

Figure 10. Schematized deformation by surface waves [24]. Character of Love waves (a) and Raleigh waves (b). 


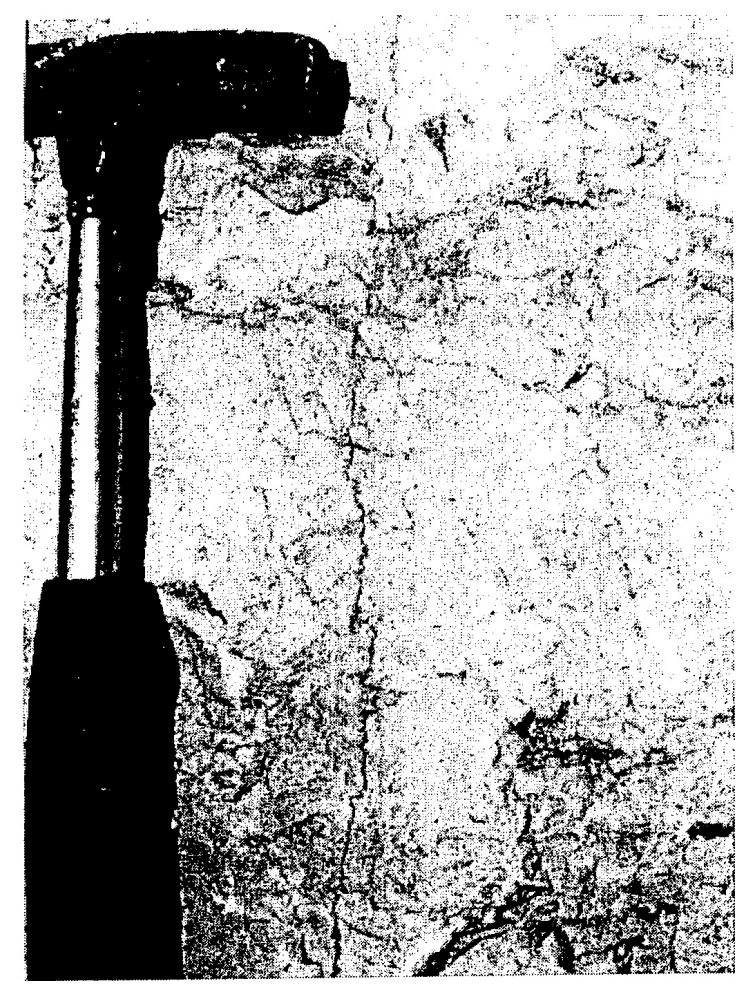

Figure 11. Horizontal stylolites hosted in Upper Cretaceous Nodular Limestone, northwest of Amman [12].

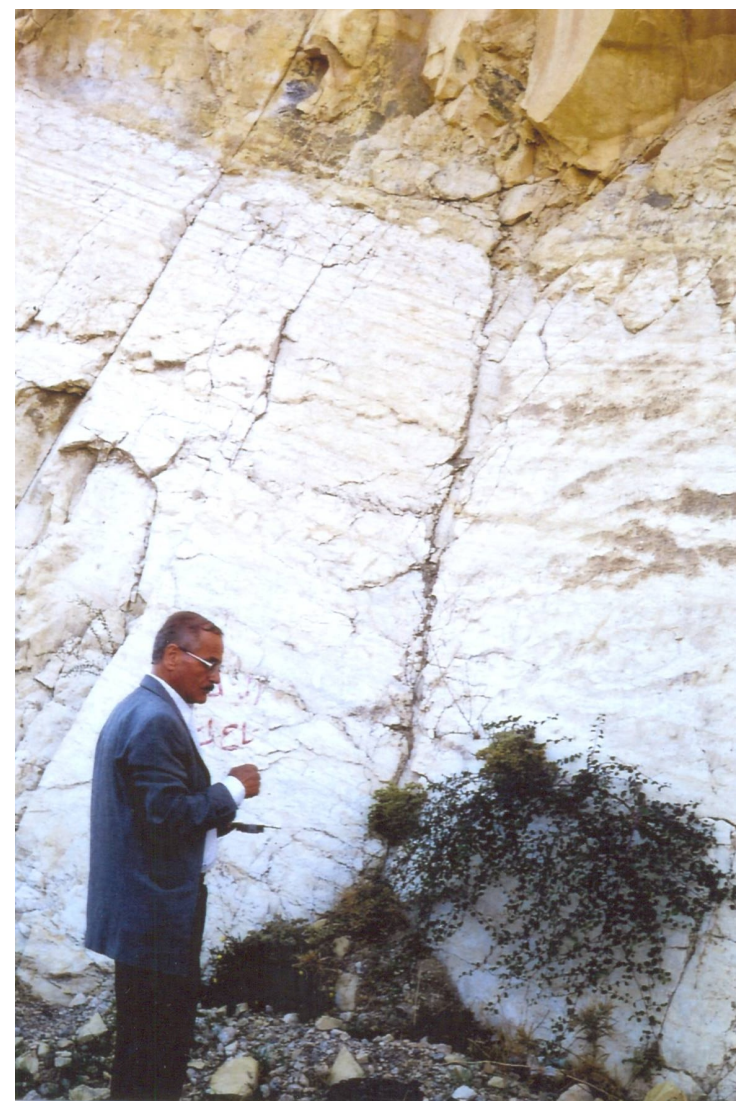

Figure 12. Slickensides on transform faults in Upper Cretaceous Nodular Limestones, northwest of Amman [12] [13]. 
decreases in the first order of distance, and it develops to the strongest wave with increasing distance from the impact site. However, by possessing ellipsoidal wave movement, the rock deformation is rather low [25].

In contrast, Love waves create horizontal rock movement (Figure 10). The dispersion of the seismic surface waves relates to the bedding planes of the rock. Reflection happens within the rock layers. If the angle of incidence becomes higher than the total reflection of the energy, it will in total remain within the rock layer. Therefore, Love waves extend over long distances by low energy loss [24].

Thus, the effect of Love waves may explain features like disharmonic folding, deformation of circular structures, horizontal stylolites and slickensides in the Upper Cretaceous sequence where alternating competent limestones (and cherts) and incompetent marlstones provide excellent conditions for relevant deformation.

Also relating to the Suffield Tests [20], the weakened target rock will be kicked on by the compressive stress pulse along an outward and upward path. A peripheral graben located between Inner and Outer Ring forms outside the crater rim and a series of concentric folds that were created by the radially directed maximum principal stress pulse. This process explains the arcuate folding zones at both Wadi Tarifi and Wadi er Ruwaishid relating to the Jordan/Iraq Border Ring Structure, as well as the folding zones located in the Western Mountain Range, Jordan. The latter ones demand one or more impact events.

Moreover, since the explosion caused permanent compressive volumetric strain, circumferential stress near the surface is the least principal stress generating vertical strike-slip faults, slicken-sides, and what is new: horizontal stylolites. Fractures and folds originate within seconds and minutes during explosion [20].

As described from the Suffield Tests, there appears widespread convolute bedding and intrusions of semiconsolidated sandstones of Lower Cretaceous age into the overlying marls and clays that requires, in addition to pore water overpressure, a regional triggering agent, possibly caused by shock waves.

Nevertheless, the Jordan Rift System may be of concern in relation to the transpressional structures as disharmonic folding and horizontal stylolites (see Ch. 5, Conclusions).

\subsection{Contact Metamorphism (Sanidine-Hornfels-Facies) of Upper Cretaceous/Tertiary Carbonate Rocks, Locally Associated with Overlying Travertines in Central Jordan and Palestine}

Strongly brecciated, partly bituminous Upper Cretaceous/Paleocene carbonate rocks covering an area of some 50 kilometers in width and 180 in length are widespread in between Central Jordan and the Western Mountain Range at Suweileh/Amman [14], further continuing to Palestine [15]. The affected rocks intercalated with phosphates and cherts, lost all their primary textures throughout the uppermost 20 meters as related to their topographic surface and were transformed to marbles.

Mineral neoformations like i.e., spurrite, perowskite, garnet, and many others indicate formation temperatures higher than $870^{\circ} \mathrm{C}$, thus presenting the Sanidine-Hornfels-Facies [29]. There also exists a low temperature mineral-facies presenting a mineral assemblage including i.e., ettringite, tobermorite, apophyllite, calcite, and many others [14]. Veins filled with calcite, green smectite, green apatite and opal-CT cut through the multicolored marbles (Figure 13).

This spectacular rock complex is also well known as "Mottled Zone" from Palestine [15] [26]-[28]. Among more than 100 mineral neoformations, spurrite, metastable larnite, garnet, diopside, anorthite, melilite, brown millerite, and even pseudo-wollastonite $\left(\beta-\mathrm{CaSiO}_{3}\right)$ were found. The latter demands a formation temperature of $1120^{\circ} \mathrm{C}[28]$.

As found in the Jordanian "Mottled Zone", green apatite does also occur at Suweileh/northwest of Amman in connection with a westward-verging flexture zone [14]. Experiments verify a transformation temperature for green apatite of $850^{\circ} \mathrm{C}$. Furthermore, the authors recognized a deformation of the apatite crystal lattice interpreting that by high $\mathrm{p} / \mathrm{t}$-conditions relating to Jordan Rift-Tectonics.

Referring to Waqf as Suwwan Impact Crater and other "crypto-volcanic" structures of the surrounding areas mentioned above, a late Pleistocene age cannot be excluded for both "Mottled Zones" of Jordan and Palestine [14]. The time-span of post-Eocene to Miocene, generally proposed, is only based on the simple fact that the stratigraphic situation across the whole target area does not allow more precise information. However, apatite age determinations in Palestine by fission track method reveal 13.6 and $16.82 \mathrm{ma}$ [29].

Marble occurrences all over the area do not show any contact with magmatites. Since the features of the "Mottled Zone" cannot be explained neither by magmatic nor by tectonic processes on the stable Jordanian Cra- 


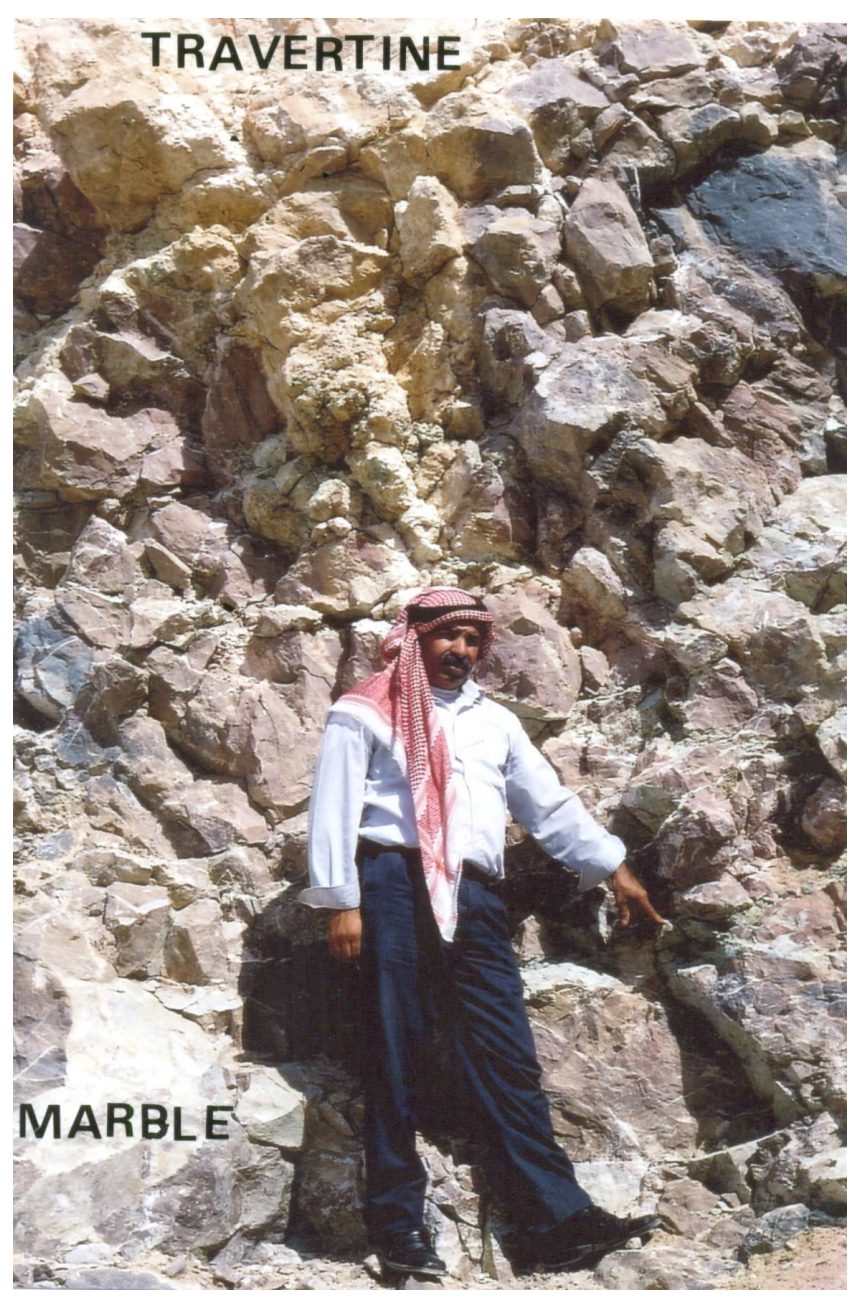

Figure 13. Multi-colored and highly brecciated marble of Sanidin-Hornfels-Impact Facies penetrated and overlain with bedded travertine, part of the "Mottled Zone" [14]. Quarry at Jizha, Central Jordan.

ton, self-combustion of the Upper Cretaceous bituminous marlstones was proposed [28]. But, i.e. at Jizha/Central Jordan (Figure 13) and other sites, the marbles are not accompanied with the latter.

Furthermore, the temperature of really self-combusted bituminous matter does not exceed the $\mathrm{p} / \mathrm{t}$-conditions of the Pyroxene-Hornfels-Facies. Dependant on the partial $\mathrm{CO}_{2}$-pressure, the Sanidine-Hornfels-Facies commences at $\sim 870^{\circ} \mathrm{C}$ by the transformation of quartz to $\alpha$-tridymite [30]. Under such conditions claystones soon begin to melt. Own experience during field work in the coal-bearing Jurassic of the Jungar Basin, Xinjiang, Northwest China, where subrecent self-combustion has been working hundreds of years or even longer, confirms these data. Local geologists confirmed that, too. Close to a coal-mine, Toutunhe Valley, Urumqi, we walked on hot hornfels-facies.

In order to realize the process that provides temperatures beyond common terrestrial contact metamorphism of huge extension, theoretical aspects with regard to the Ries Crater, Germany (20 kilometers in diameter) will be helpful for comparison as follows [25]: A cloud of gas and rock vapor of a few cubic kilometers in volume originates during the impact. In a supersonic flowing process (excavation) the temperature decreases from about $10,000 \mathrm{~K}\left(0^{\circ} \mathrm{C}=273 \mathrm{~K}\right)$ in the impact centre to about $1700 \mathrm{~K}$ outwards during an adiabatic extension where the cloud volume grows up to a radius of 20 - 25 kilometers at 1 bar pressure. The cloud velocity varies within a few kilometers (wildfire, whirlstorm). Impact-initiated super cyclonic whirlstorms generate temperatures up to $1800^{\circ} \mathrm{C}$ and would work as matchstick for inflammation of locally exposed bituminous rocks [31]-[35]. 
In case of an oblique impact, the gas cloud still keeps the horizontal impulse (direction) of the impact body while in contrast, the shock waves spherical-concentrically spread out into the sub-ground [25].

At incidence angles of $10^{\circ}-20^{\circ}$, a ricochet situation is given (Figure 14), where fragments of the bolide are possibly repeatedly jumping on outcropping rocks leaving a chaotic stripe of Ricochet-Impact-Thermo-Cataclysm behind it [31].

Thus, both in combination, Love waves [24] and ricochet-bearing gas clouds may have generated the brecciated Sanidine-Hornfels-Impact Facies of the "Mottled Zone". Furthermore, the whirlstorm took fragments of both impactor and outcropping rocks with it to crash Upper Cretaceous limestones and phosphorites along its west-northwest-striking pathway.

A result of such a crash would be the apatite crystal-lattice deformation, recognized in phosphorites at Baq'a Structure, Suweileh [13] [14]. It is to be stressed that the formation temperature of pseudo-wollastonite $\left(1120^{\circ} \mathrm{C}\right)$ appears unrealistic for a cratonic setting like the target area but as evidence for impact processes.

Thus, post-Paleogene impact events onto the Arabian Plate may have caused not only Jebel Waqf as Suwwan Impact Structure, but also other circular structures ("crypto-volcanic"), disharmonic folding, horizontal stylolites, slickensides, and last not least the "Sanidine-Hornfels-Impact Facies of the "Avenue of Ricochet-Impact-Thermo-Cataclysm" between Central Jordan and Palestine along a significant west-northwest/east-southeast-striking axis.

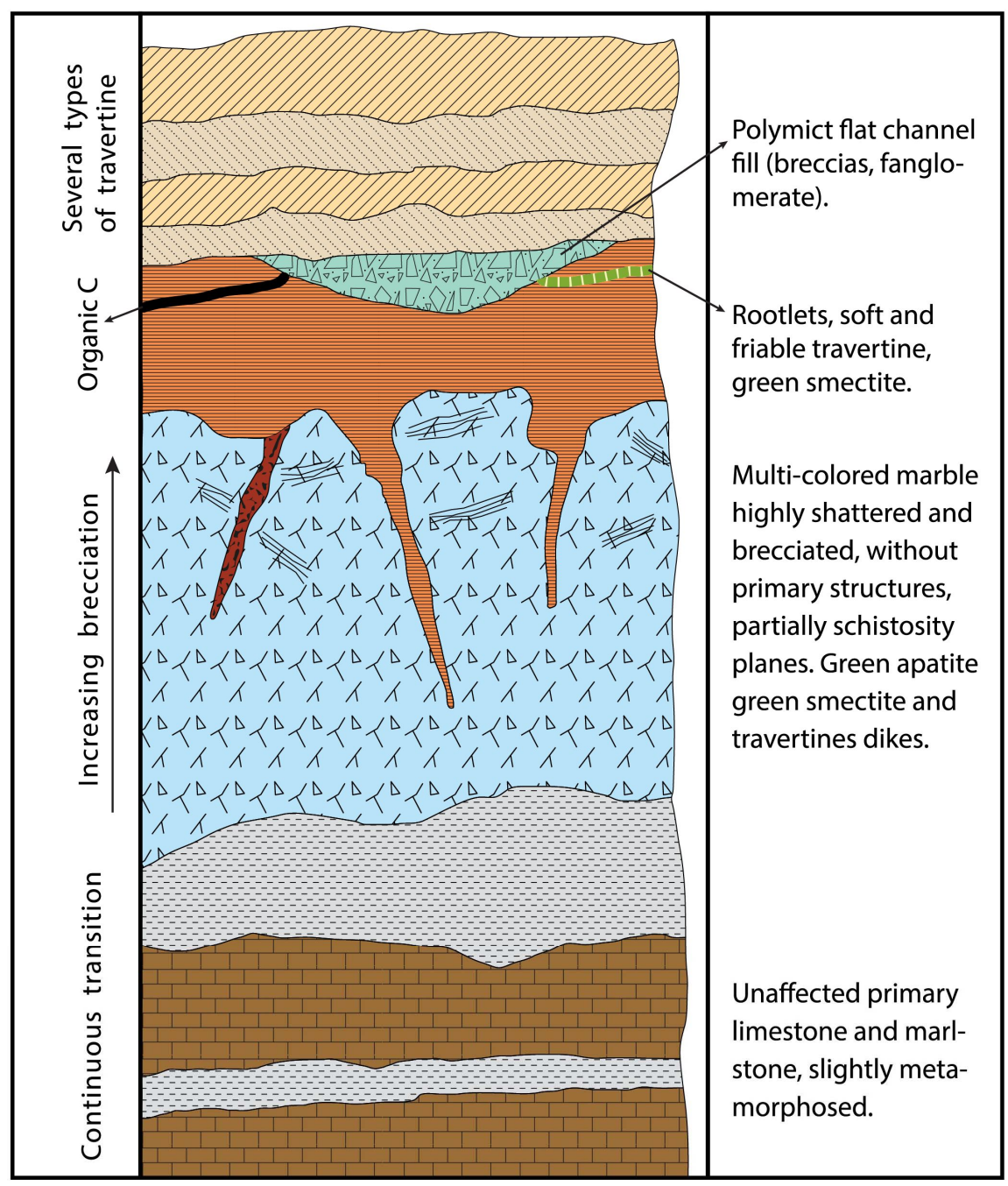

Figure 14. Schematic profile of highly effected marble of Sanidine-Hornfels-Impact Facies overlain with bedded travertine as low temperature-impact facies. Quarry at Jizha, Central Jordan. 


\subsection{Impact-Related Low Temperature Travertines}

The "Mottled Zone" of Jordan exhibits a broad variety of travertines overlying and genetically relating to the highly affected marbles (Figure 13, Figure 14). The underlying primary Upper Cretaceous carbonate rocks show a continuous transition of unaffected to extremely brecciated rocks from base to top. Upwards the primary rocks become increasingly recrystallized, shattered, and multi-colored as a result of top-related deformation and mineralization. Green apatite, green smectite, and travertine dikes penetrate and fill veins and voids of the marble (Figure 13, Figure 14).

The overlying massive and bedded travertines consist of several alternating facies types differing in crystal size, porosity, and texture (Figure 15). Thin soot-lyers and rootlests as well as green smectite layers intercalate the travertine. Flat channels filled with polymict breccias, conglomerate- and fanglomerate-like deposits, indicate transport and reworking processes (Figure 15). The travertine and associated minerals precipitated from ascending and circulating hydrothermal water under basic conditions. The triggering of "wells" followed by an explosive ascent of groundwater caused by a prehistoric earthquake in Connecticut, USA may be used for comparison [36].

The rock sequence at Jizha, Central Jordan reveals the following genetic and temporal sequence under ricochet impact conditions:

-Sanidine-Hornfels-Impact Metamorphism of the upper 20 meters of more or less bituminous limestones at temperatures higher than $870^{\circ} \mathrm{C}$ accompanied by processes of brecciation, cracking, and de-carbonatization $\left(\mathrm{CaCO}_{3} \rightarrow \mathrm{CaO}+\mathrm{CO}_{2}\right)$, like below [37].

-Explosive eruptions of tremendous volumes of groundwater and formation water, generation of calciumhydroxide $\left(\mathrm{CaO}+\mathrm{H}_{2} \mathrm{O} \rightarrow \mathrm{Ca}(\mathrm{OH})_{2}\right)$.

-Low temperature mineralization along fractures and dikes, voids and caverns by green apatite, green smectite, opal-CT, carbonate minerals and others (retrograde mineralization).

-Ascending hydrothermal groundwater led to the formation of dikes (Figure 16), pools, and lakes, immediately followed by mineral neoformation, and finally reworking processes [38].

Since a genetic relationship of both marble and travertine does exist, the concept of self-combustion cannot be applied at temperatures above $870^{\circ} \mathrm{C}$ where the travertine would underlay de-carbonatization.

The Suffield Experiments make evident that the formation of the "Avenue of Ricochet-Impact-Thermo-Cataclysm" demands an oblique impact (Figure 17). Moreover, they make clear that during explosion and excavation, the radial and concentric fissures and fractures opened in the highly heated carbonate rocks down to the

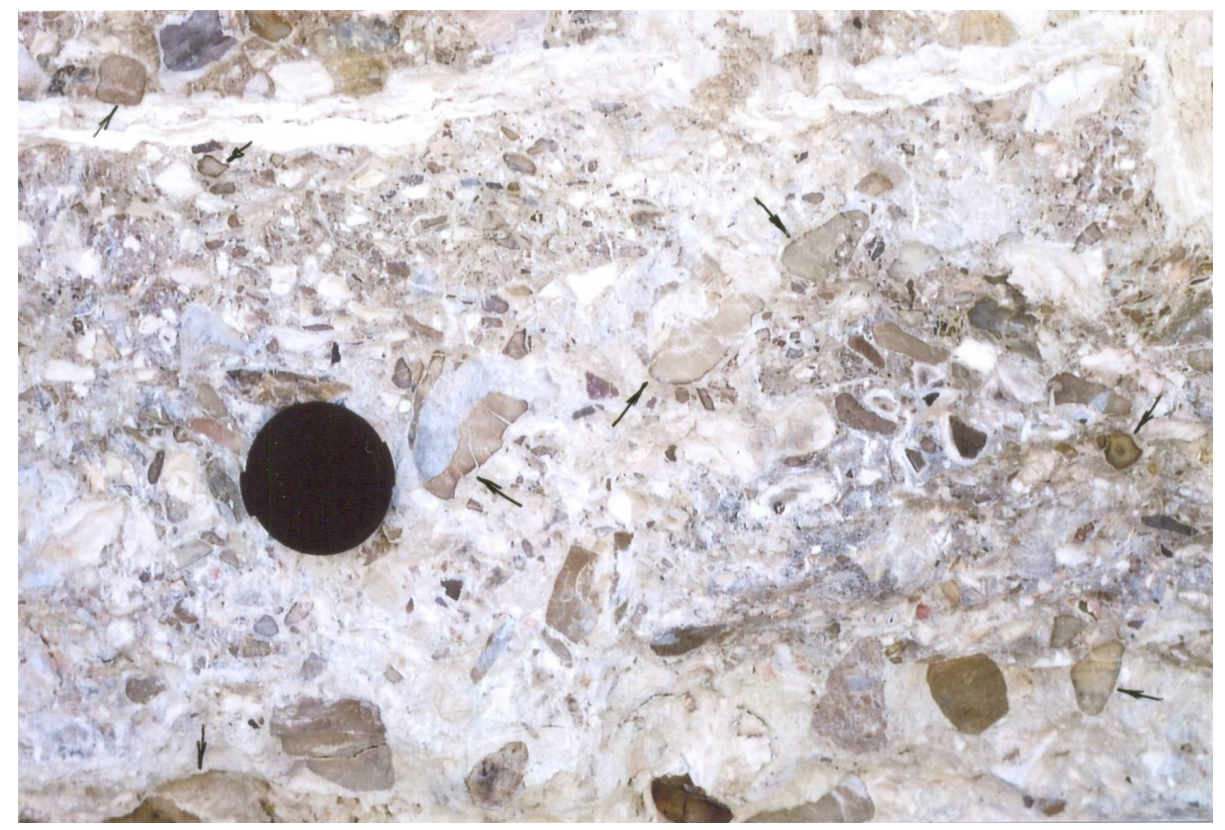

Figure 15. Resediments poorly sorted and intercalating bedded travertine, quarry at Jizha, Central Jordan. Note fried surfaces of pebbles. 


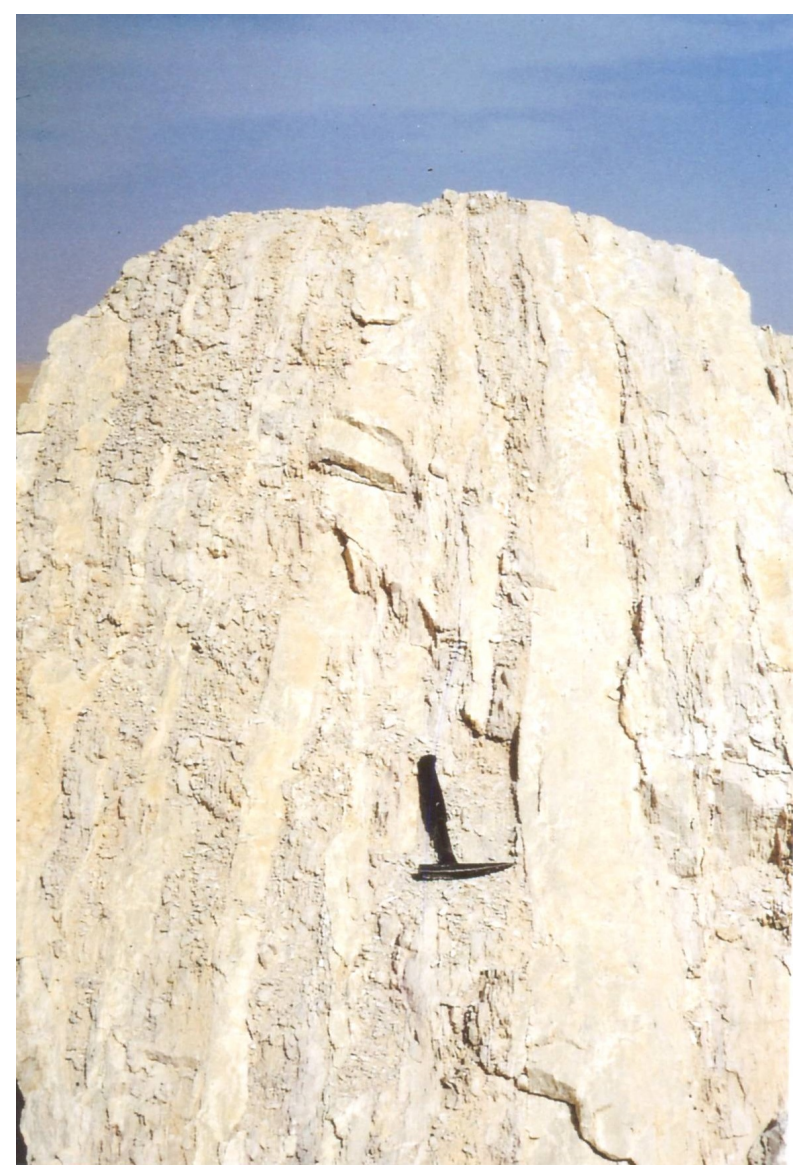

Figure 16. Travertine dike consisting of several phases of carbonate precipitation with alternating crystalinity, cutting vertically through brecciated marble of "Sanidine-Hornfels-Impact Facies" in a quarry at Jizha, Central Jordan.

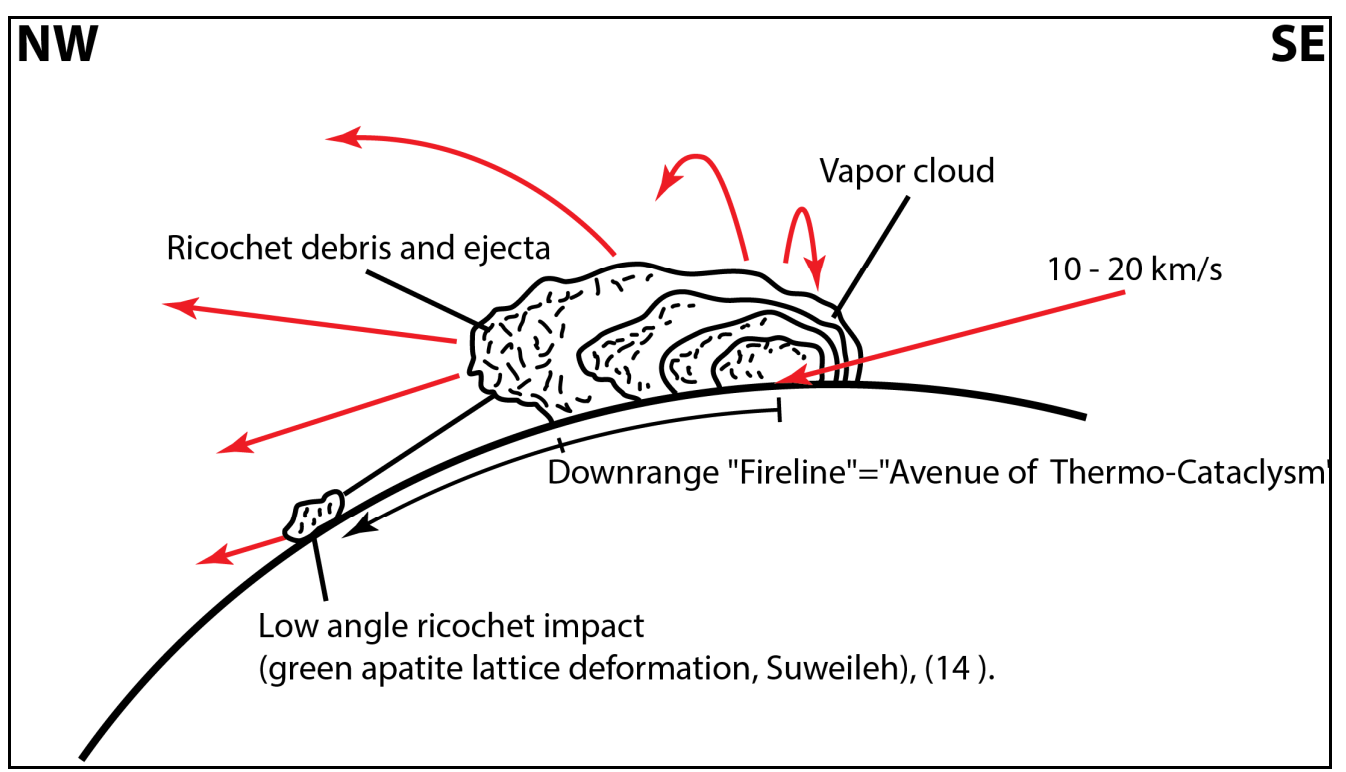

Figure 17. Ejecta and whirlstorm effects $\left(\sim 1800^{\circ} \mathrm{C}\right)$ after an oblique impact $\left(10^{\circ}-20^{\circ}\right)$ after [31], applied to the "Avenue of Ricochet-Impact-Thermo-Cataclysm" exhibiting "Sanidine-Hornfels-Impact Facies" (see Figure 3(b)). 
original water table [20]. High fluid pressures develop in the rock mass. So there is both impact and hydraulic fracturing. Outflow of water and the mineralization of dikes follow, immediately.

\subsection{Supplementary Data to Jebel Waqf as Suwwan Impact Crater}

Though this structure has been well investigated by geologic and geophysical methods [2] [4], there still remains the necessity of reliable age determination. Since the target area is predominantly composed of chert-intercalated carbonate rocks and Lower Cretaceous sandstones in the Central Uplift, suitable minerals and rocks are rather restricted to be applied. However, fall-back material recovered within the Inner Ring close to the Central Uplift undoubtedly reveal evidence of primary rock glass that would allow to apply the fission track method [39]: chert bombs own fluidal surface textures (Figure 18) but are unfortunately devitrified to fine-crystallized low temperature $\mathrm{SiO}_{2}$-modifications ( $\beta$-quartz).

Furthermore, a Lower Cretaceous sandstone sample recovered at the rim of the Central Uplift, incorporates the complete cooling process after having passed the $\mathrm{SiO}_{2}$-melting point $\left(1714^{\circ} \mathrm{C}\right)$ [40]. Figure 19 shows stalklike pseudomorphs of $\beta$-cristobalite (lussatine) [40]. Even the so-called "ballen-structure" can be recognized (Figure 20) proving the transformation of $\alpha$-cristobalite to $\beta$-cristobalite at $267^{\circ} \mathrm{C}$. The fractures arranged in regular distance are caused by volume reduction $(\sim 7 \%)$. Thin sections also show plates of pseudohexagonal pseudomorphs of $\beta$-tridymite owing typical triplets (Figure 21). It recrystallized from $\alpha$-tridymite at $\sim 163^{\circ} \mathrm{C}$ followed by the transformation to chalcedony ( $\beta$-quartz). Hence, this rock sample is mainly composed of $\beta$ cristobalite (pseudomorphic), $\beta$-tridymite and chalcedony ( $=\beta$-quartz) as recrystallisation product [40].
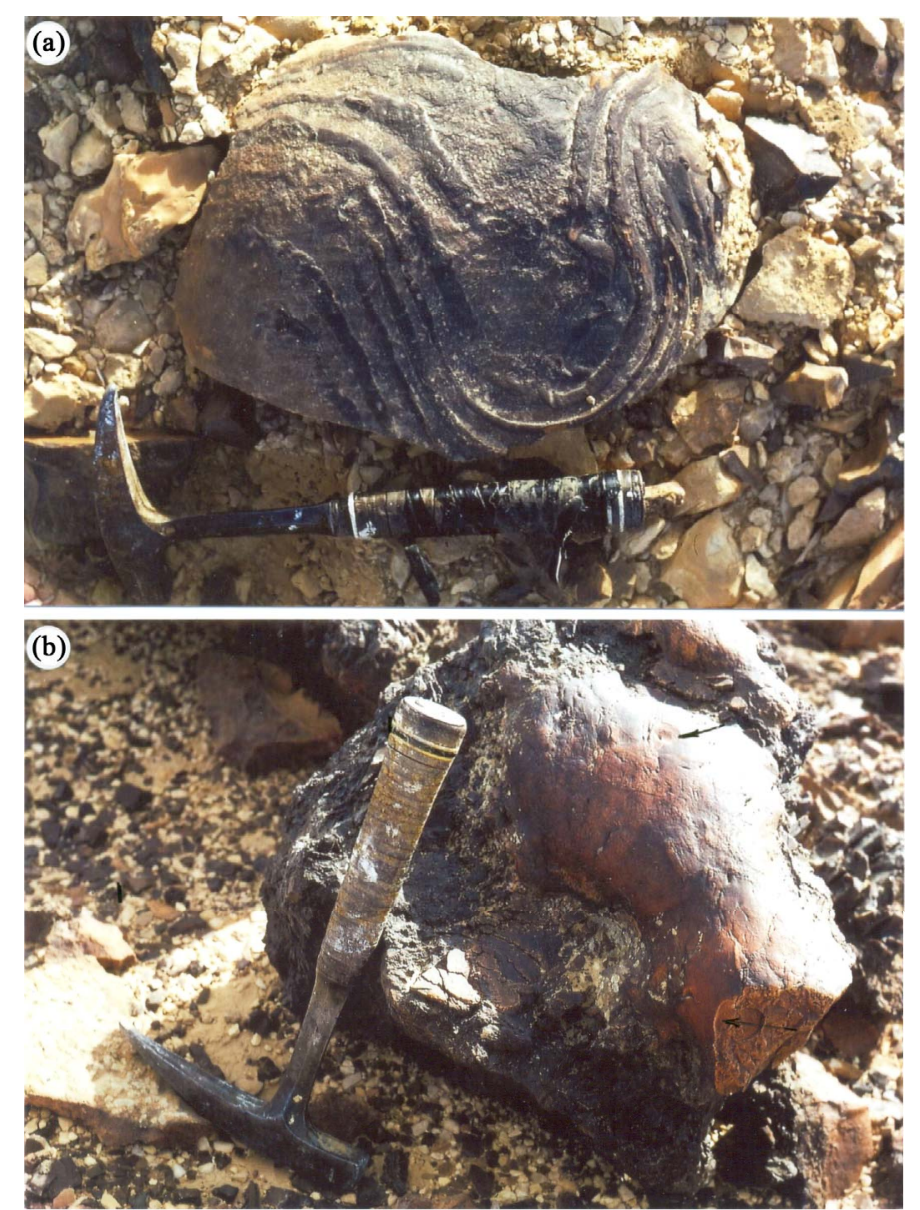

Figure 18. Chert-bombs revealing fluidal surface textures (chertglass!), but unfortunately devitrified to fine-crystallized low temperature $\mathrm{SiO}_{2}$-modifications [see 2.5]. Note little impact onto the melted surface of high viscosity (b). 

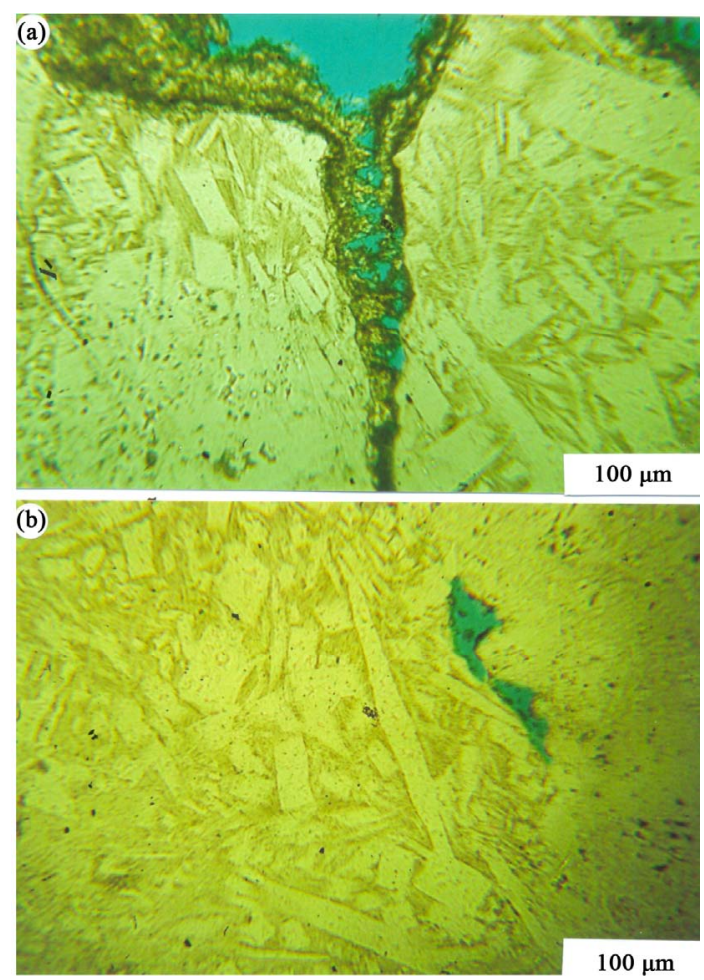

Figure 19. Stalk-like pseudomorphs of $\beta$-cristobalite recrystallized from $\alpha$-cristobalite, and following transformation to chalcedony $(\beta$-quartz) [39]. Note carbonate rim cement on fissures. Originally melted Lower Cretaceous Kurnub-Sandstone recovered from the Central Uplift (JWS), parallel nicols.
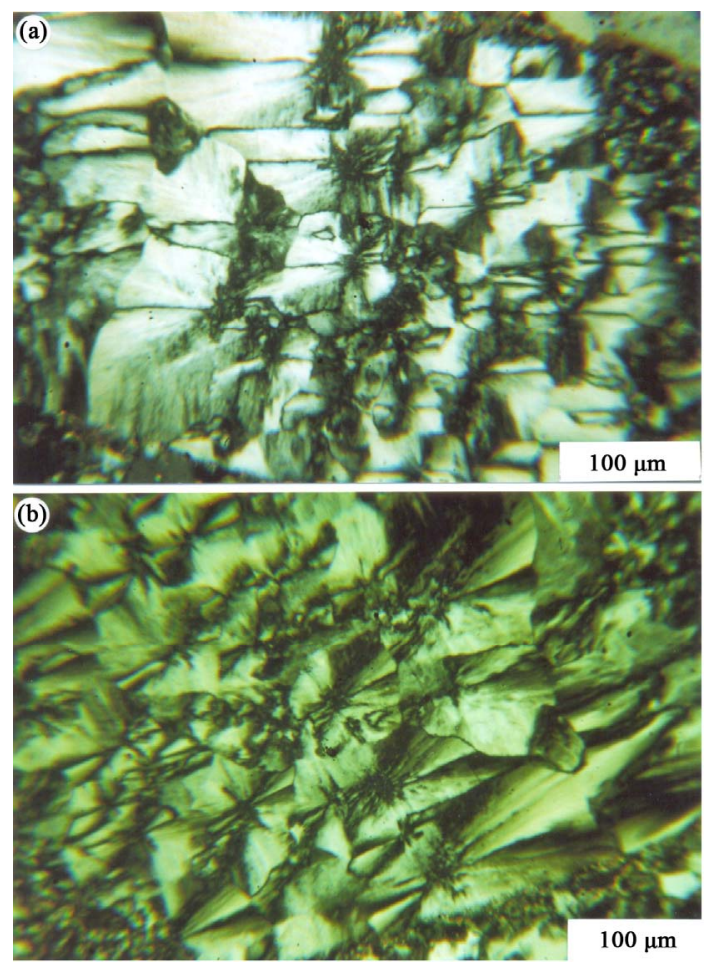

Figure 20. "Ballen-Structure" [39] generated by the transformation of $\alpha$-cristobalite to $\beta$-cristobalite. This typical structure is a result of volume reduction $(\sim 7 \%)$; following transformation to chalcedony. Originally melted Kurnub-Sandstone from the Central Uplift (JWS), crossed nicols. 

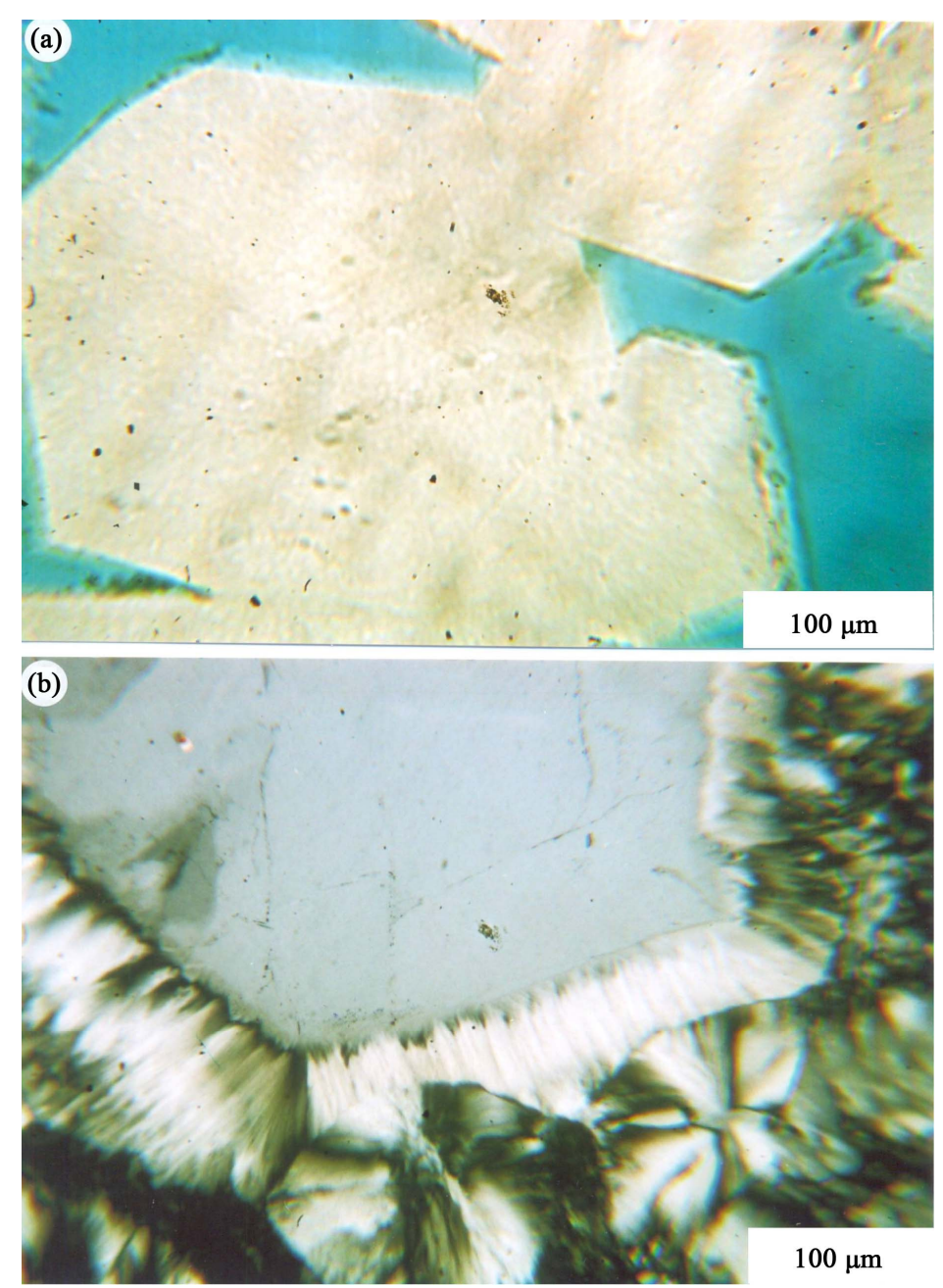

Figure 21. Plates of pseudo-hexagonal $\beta$-tridymite showing typical triplets [39]. Further recrystallisation to chalcedony. (a) parallel nicols; (b) crossed nicols. Note chalcedony rim cement. Originally melted Kurnub-Sandstone from the Central Uplift (JWS).

Whereas coesite is placed in the same $\mathrm{p} / \mathrm{t}$ field like shatter cones, stishovite appears together with PDF in quartz (Figures 3(a)-(b)). However, in order to verify the existence of both $\mathrm{SiO}_{2}$-minerals, chemical concentration by hydrofluoric acid for X-ray analysis is necessary as done with silicate rocks of the Ries Crater [41]. Very few and tiny crystals of high refractive index can be recognized by pocket lens in highly deformed chert-breccias which may give hope for identification in the future.

Fall-back samples recovered from the rim of the Central Uplift contain angular chert fragments still sticking in holes of the same size and shape within the limestone. They obviously hit the latter during excavation and air transport, when their temperature was yet above that of de-carbonatization $\left(870^{\circ} \mathrm{C}\right)$. This impact feature seems unique, probably never seen before. We term it "Chert-Carbonate-Impact-Chess Game" (Figure 22).

Obviously, fall-back material derived from the zone between Central Uplift and Inner Ring, promise high $\mathrm{p} / \mathrm{t}$ conditions of impact metamorphism (Figures 3(a)-(b)) as well known from the Ries Crater [42] [43]. Therefore, it needs one, or better, two wells for coring this zone where the target rocks underwent a steep excavation angle and an accordingly vertical fall-back near the centre of the structure. In such case, hope may arise to encounter non-devitrified rock-glass of chert and sandstone preserved for applying fission tracking [39].

The recent drilling project focused on the zone between Inner and Outer Ring without finding any impact deformation features and, at all, very little, more or less brecciated and reworked limestones and cherts, rather wadi sediments than as fall-back [44]. The reason lies in de-carbonatization of the target rocks (above $870^{\circ} \mathrm{C}$ ). Thus, some $90 \%$ of the stratigraphic column just "disappeared" as gas and rock vapor. 

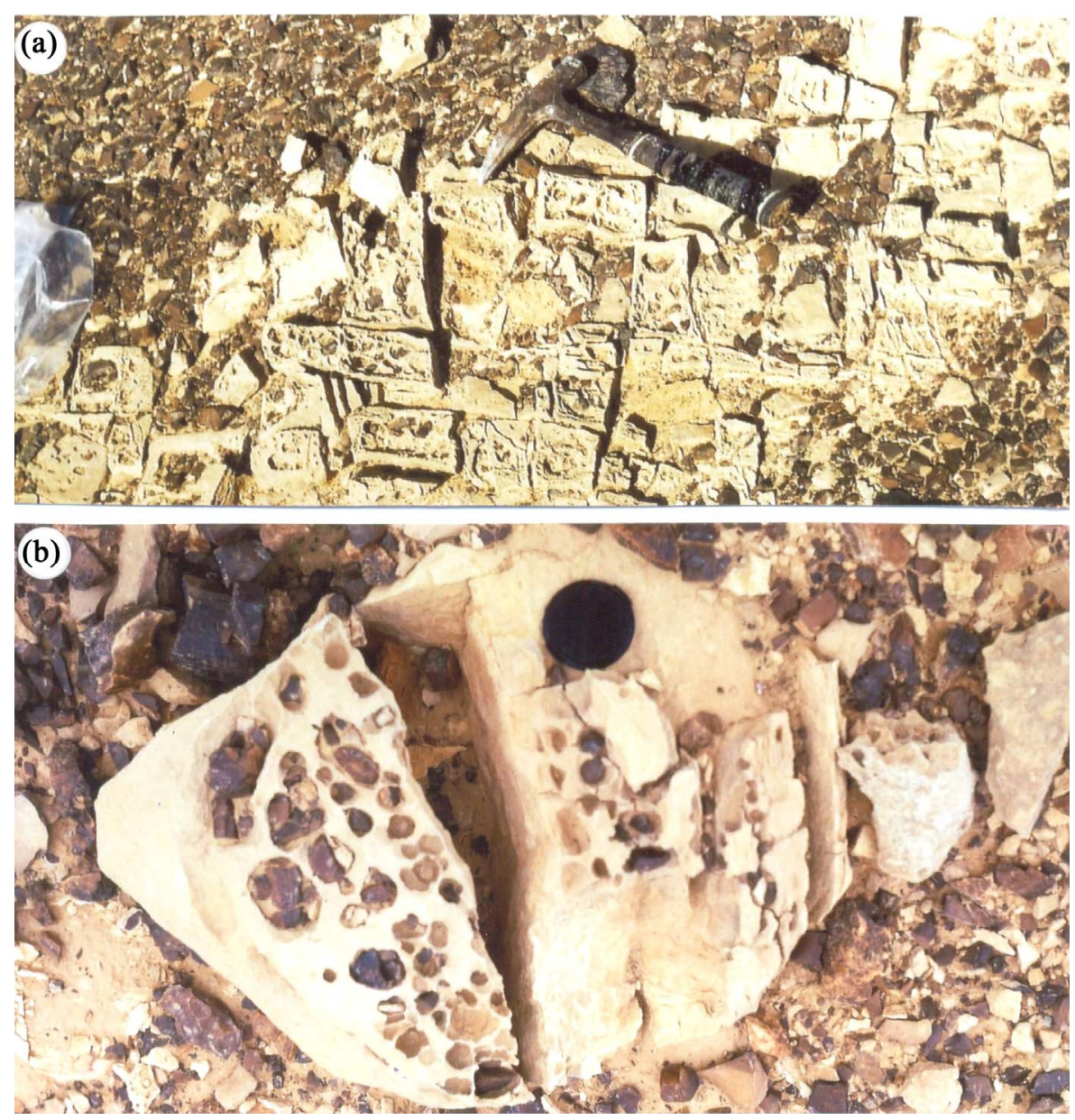

Figure 22. Angular chert fragments still sticking in limestone after having been hit during excavation (air transport) at temperatures above $870^{\circ} \mathrm{C}[1]$ (=Chert-Limestone-Impact-Chess Game).

The evidence of melted Kurnub-Sandstone (above $1714^{\circ} \mathrm{C}$ ) allows approximately calculating the volume of vaporized carbonate rocks in a model by using the thickness of the overlying Upper Cretaceous/Paleogene strata (Figures 23(a)-(b)).

Model (a) applies some $\sim 1000$ meters overburden of carbonate rocks [16], Model (b) about 330 meters according to surficial field data [4] [45]. Relating to Figures 3(a)-(b), in the first case where the base of carbonate rocks coincides with the prominent reflector at 1000 meters depth [4], the total volume of vaporized carbonate rocks amounts at least to $\mathrm{V}_{\text {total }}=2.1 \mathrm{~km}^{3}\left(\right.$ centre $\left.-1714^{\circ} \mathrm{C}\right)+\mathrm{V}\left(1714^{\circ} \mathrm{C}-870^{\circ} \mathrm{C}\right)-\mathrm{V}_{\text {chert }}$. In the second case, the total volume amounts to at least $\mathrm{V}_{\text {total }}=0.8 \mathrm{~km}^{3}$ (center $\left.-1714^{\circ} \mathrm{C}\right)+\mathrm{V}\left(1714^{\circ} \mathrm{C}-870^{\circ} \mathrm{C}\right)-\mathrm{V}_{\text {cher }}$.

The high thickness difference between both Models (a) and (b) lies in the uncompleted sedimentary sequence in the crater vicinity, whereas Bender [16] gives a reliable thickness average of the relevant strata through Central and Northeast Jordan.

Nevertheless, there undoubtedly "disappeared" a gigantic volume of carbonate rocks as gas and rock vapor. Consequently, it is not surprising we are missing impact features in the core materials in between Inner and Outer Ring of JWS Impact Structure.

Moreover, such impacts produce huge volumes of ash and dust that may contribute to Holocene "loess-like" deposits in Jordan [16] and possibly even throughout the so-called "Fertile Crescent" of the Near and Middle East [46]. Impact ash-deposits provide excellent fertility!

From Jebel Waqf as Suwwan comes a further confirmment that shatter cones may have a broad variety of structures. In addition to Figure 3(b) and Figure 4(d) in [2], Figure 24 shows a very fine-radial striation of ra- 


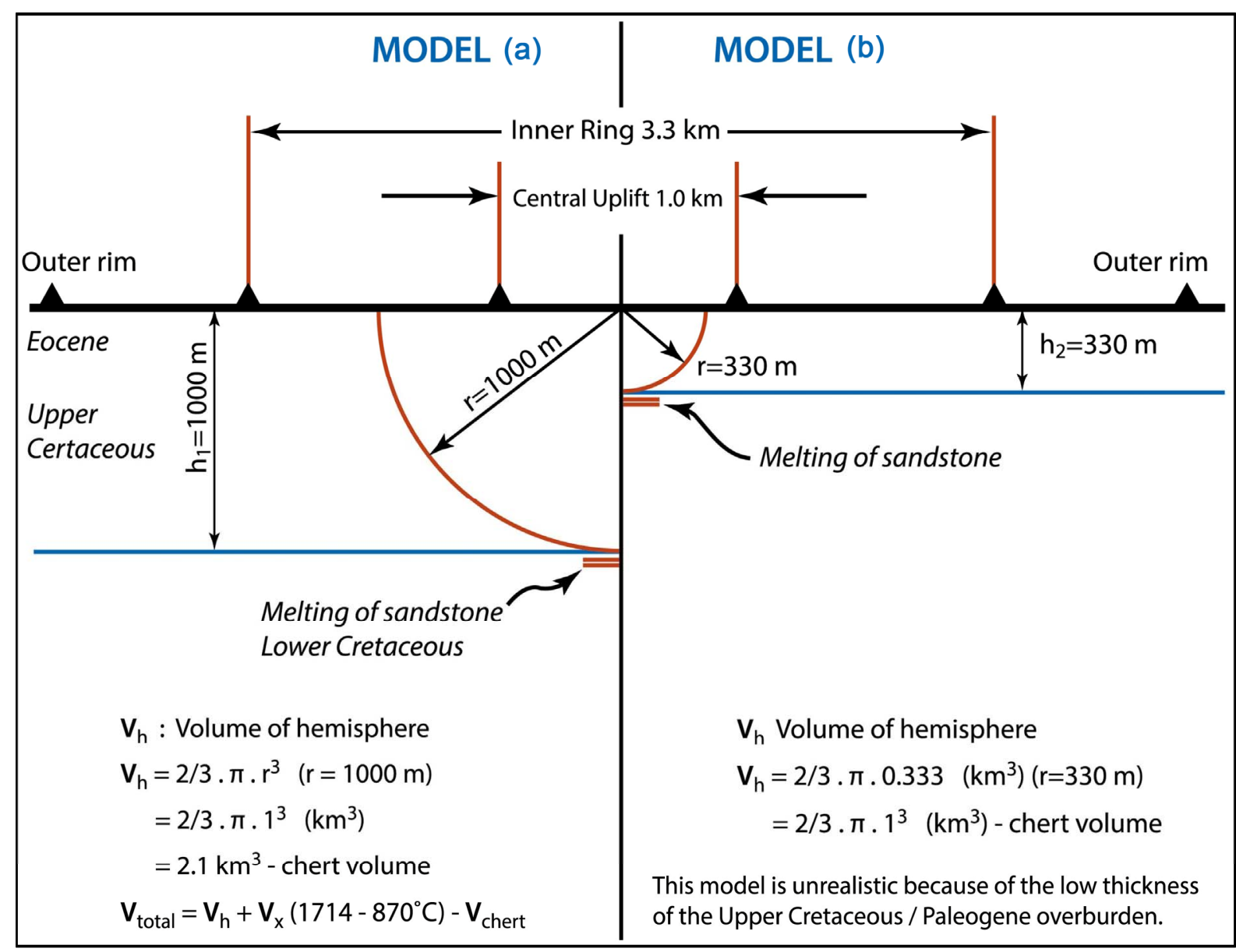

(a)

(b)

Figure 23. Models (a) and (b) showing, dependant on thickness of overlying Upper Cretaceous/Paleogene carbonate rock cover, the due realms of de-carbonatization in hemisphere shape (comp. Figure 3(a)). (a) $\sim 1000$ meters overburden [16] = depth of top Kurnub-Sandstone where $\mathrm{SiO}_{2}$-melting took place. Carbonate vaporization would comprise at least 2.1 cubic kilometers between centre and $1714^{\circ} \mathrm{C}$-line. (b) $\sim 330$ meters overburden $(4,44)=$ depth of top Kurnub-Sandstone where $\mathrm{SiO}_{2}$-melting took place. Carbonate vaporization would comprise at least 0.8 cubic kilometers between centre and $1714^{\circ} \mathrm{C}$-line.

tiatiform remarkable length in a limestone sample recovered from near the rim of the Central Uplift.

It should be stressed that, on our first field trip to this structure, an ejecta fan of chert-breccia deposited close to the Inner Ring, left the spontaneous impression as the impact event would just has occurred "a few days ago": there is not any evidence of following sedimentologic processes like reworking, sorting, and transport. So, that hints on a Holocene age.

The Suffield Tests confirm the following features of the Jebel Waqf as Suwwan Impact Crater except the Peripheral Graben of the Snowball Crater, corresponding to the concentric realm between Inner and Outer Rim of JWS. Low angle thrust and shear fractures as results of post-explosion excavation relate to the brecciated zone in Figure 25(b) [20]. The drainage systems of both structures are similar and comparable with the Bosumtwi Crater, Africa [20]. The transition from the transient crater to the final simple crater results in a diameter increase of about $19 \%$ [20].

When one let wandering his view along the target area hitherto regarded, one may continue towards southeast, to Saudi Arabia (Figure 26). There are more huge arcuate structures without age data, and not to forget the Wabar Craters in the legendary Empty Quarter (the Rub' al-Khali) [47].

It seems that a northwest/southeast-striking zone between the Arabian Sea and Palestine may be occupied by possible impact sites and according impact features.

In this paper the calculated age-data are generally given by radiocarbon yr.cal.B.P. Some of the reference data 


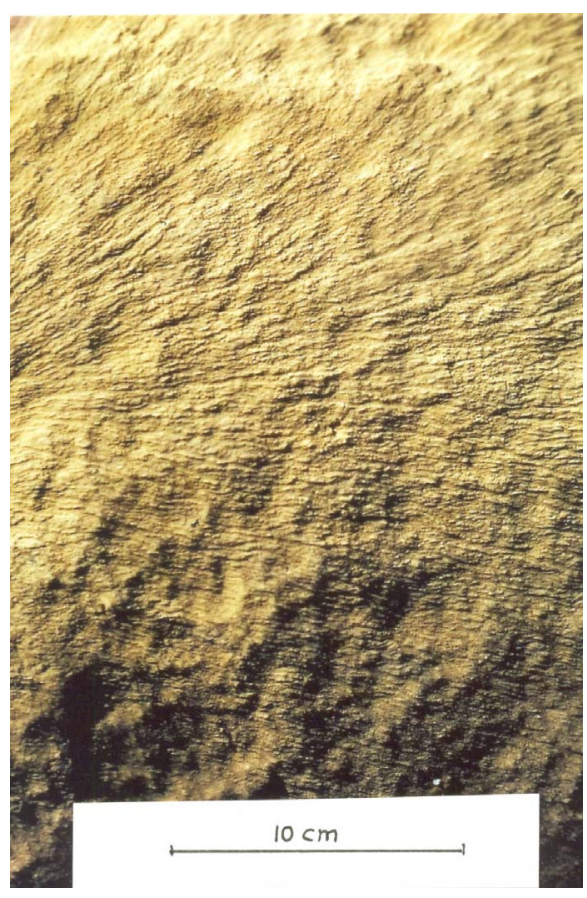

Figure 24. Rare type of striated ratiatiform shatter cone from the Inner Ring of JWS Impact Crater.

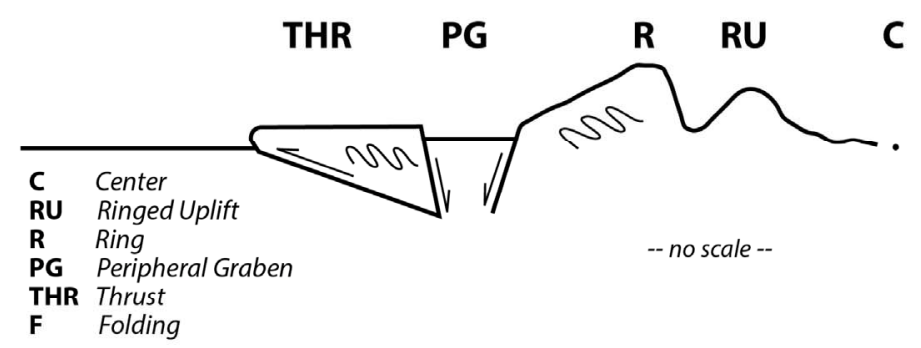

(a)

WEST

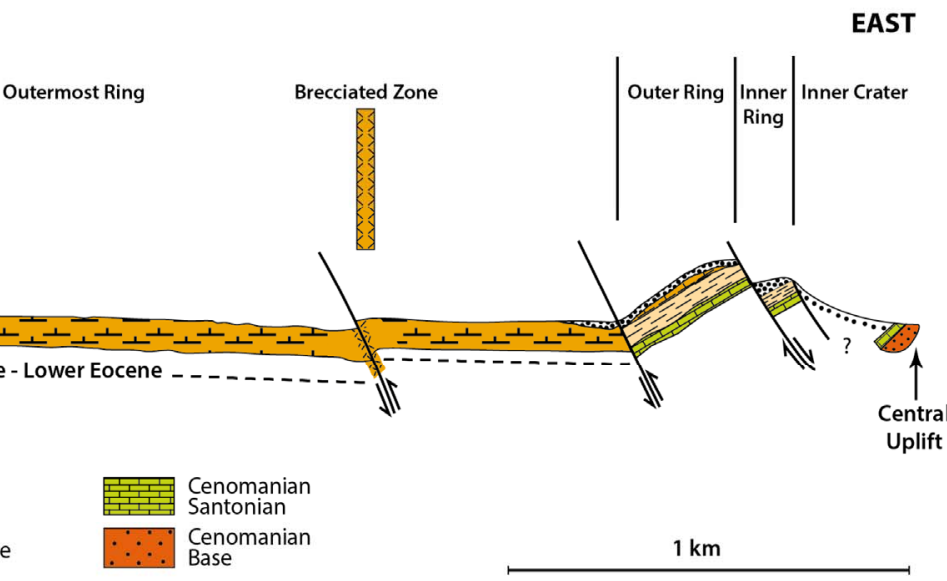

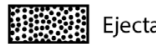

$\vdash$ 十 Middle Eocene

$E=E-$ Campanian-

(b)

Figure 25. Comparison of both prairie flat 500 tons Explosion Structure [(a): 20] and Jebel Waqf as Suwwan Impact Crater [(b): 1,4]. 


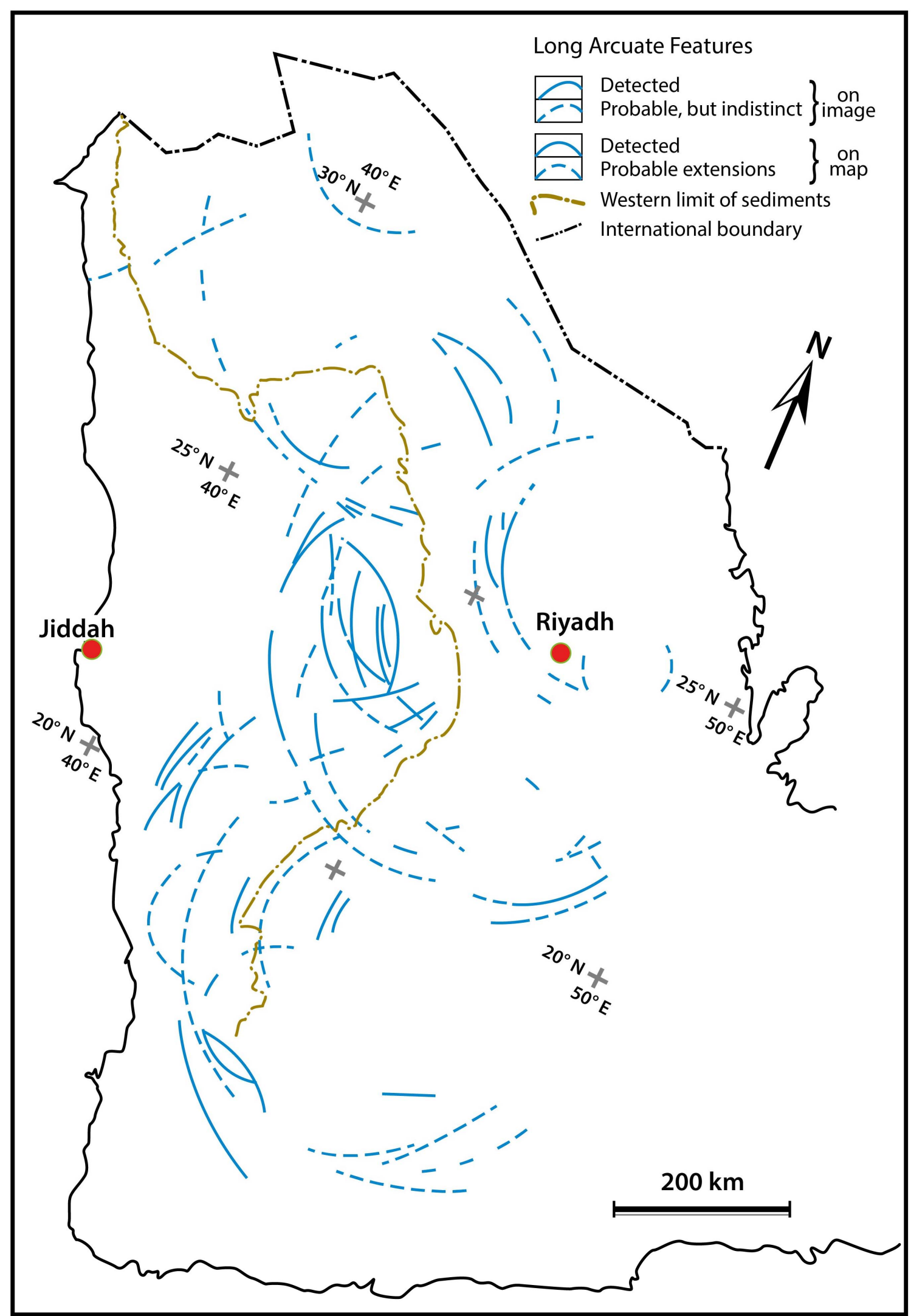

Figure 26. Arcuate structure remnants across Saudi Arabia [20] (Figure 5 in [21]). 
relate to yr B.C.* to be transformed to yr B.C.* $+2000 \mathrm{yr}=$ B.P.*. The latter value is 50 years higher than primary B.P. data from other references since based on yr 1950 A.D. by international agreement.

\section{Coming and Going Neolithic and Bronze Age Cultures in the Near/Middle East Relating to Rapid Climate Change (RCC)}

If one asks for reasons of RCC, Earth's orbital and solar activity variations, mega-volcanic outbreaks, and major impacts as well, are the most relevant factors.

Hoyle [48], a British astrophysicist argued for possible impact events on Earth every $1600 \mathrm{yr}$ by fragments of a repeatedly returning large comet that has been possibly loosing material when passing the Earth's orbit relatively close to the Sun. Thus, consecutive collisions with celestial bodies of our planetary system might have happened on 12,700, 11,100, 9500, 7900, 6300, 4700, 3100 yr B.P.*, etc. see also [34].

Climate variability during Holocene has been excellently analyzed by some 50 globally distributed records [49]. Significant RCCs occurred through the periods 9000 - 8000, 6000 - 5000, 4200 - 3800, 3500 - 2500, 1200 1000 , and $650-150 \mathrm{yr}$ cal. B.P. All of them underwent polar cooling, wetlands in the Mediterranean, tropical aridity, and major atmospheric circulation changes.

In addition, Case 1 relates to the Middle/Upper Pleistocene boundary as a hiatus/discordance that separates mid-Pleistocene basalts (Figure 27, [16]) from Upper Pleistocene gravels. If the some 60 kilometers large "Collapsed Caldera" (Figure 1, Figure 7) could be verified as a real crater, there would be, because of its size, a very high probability of being an impact crater. Widespread gravel deposits, landslides, "loess-like" sediments, indications on hazardous flooding, and possible triggering of the youngest basaltic volcanism in Northeast Jordan would be relevant around the Pleistocene/Holocene boundary.

\subsection{Case 2}

Atmospheric methane and $\delta^{18} \mathrm{O}$-data analyzed from Grip ice-cores of Greenland, define the last glaciation period, Younger Dryas (12,700 - 11,500 yr B.P.), as the end of the Pleistocene [50]. It caused ice-covered areas in high latitudes and wetlands of moderate climate in lower latitudes. Two droughts intercalate in the Mediterranean parallel to tropical Africa.

As Figure 28 shows, the Younger Dryas starts with Hoyle's "possible" Comet 1-Event and with the end of the Natufian Culture $\left({ }^{14} \mathrm{C}: 14,500\right.$ - 12,300 yr B.P. $)$ that appeared in Jordan and Israel as a mixture of semi- nomads and settled farmers [51]. Excavated implements give evidence on hunting animals and plant food.

In a pre-agricultural stage, the early ABU HUREYRA CULTURE, Syria $\left({ }^{14} \mathrm{C}, 13,000-11,500 \mathrm{yr}\right.$ B.P. $)$ approximately coincides with the Younger Dryas period. Food consisted of wild animals and a broad variety of cereals [52].

\subsection{Case 3}

Around the end of the Younger Dryas, shortly prior to the Pleistocene/Holocene boundary, a drought occurred in the Near East that caused a higher salinity in the Red Sea and led to the precipitation of aragonite layers [53] [54]. ${ }^{14} \mathrm{C}$ - and $\delta^{18} \mathrm{O}$-data indicate an age of $11,600 \mathrm{yr}$ B.P. in average.

While the early stage of the ABU HUREYRA CULTURE vanished at that time for about $500 \mathrm{yr}$, the temperatures significantly increased continuously during the Pre-Boreal (11,500 - 10,000 yr B.P.) [50].

Plato (427 - 347 yr B.C.) reported on a Cataclysm-Event in connection with the destruction of "ATLANTIS", $9000 \mathrm{yr}$ before his time [55] which means the Pleistocene/Holocene boundary.

Just around 11,000 yr B.P. Hoyle's Comet 2 re-appeared while the ABU HUREYRA CULTURE re-developed [53] and the early foundation of Jericho started [57].

\subsection{Case 4}

After the Pre-Boreal, as the first interval of the Holocene [57] during increasing temperature, followed a period of acid events found in ice cores of Greenland [58]. The most significant and strongest one dates on $9640 \mathrm{yr}$ B.P.*, others range in between 9910 and 9090 yr B.P.*. Obviously, there seems no relation known to major volcanic outbreaks through this interval. But from the same time-span absolute age data are available concerning tektite strewn fields (fission track: 10,000 - $9545 \mathrm{yr}$ B.P.*, [59]), extinction of mammoth $\left({ }^{14} \mathrm{C}: 9610 \pm 300 \mathrm{yr}\right.$ 


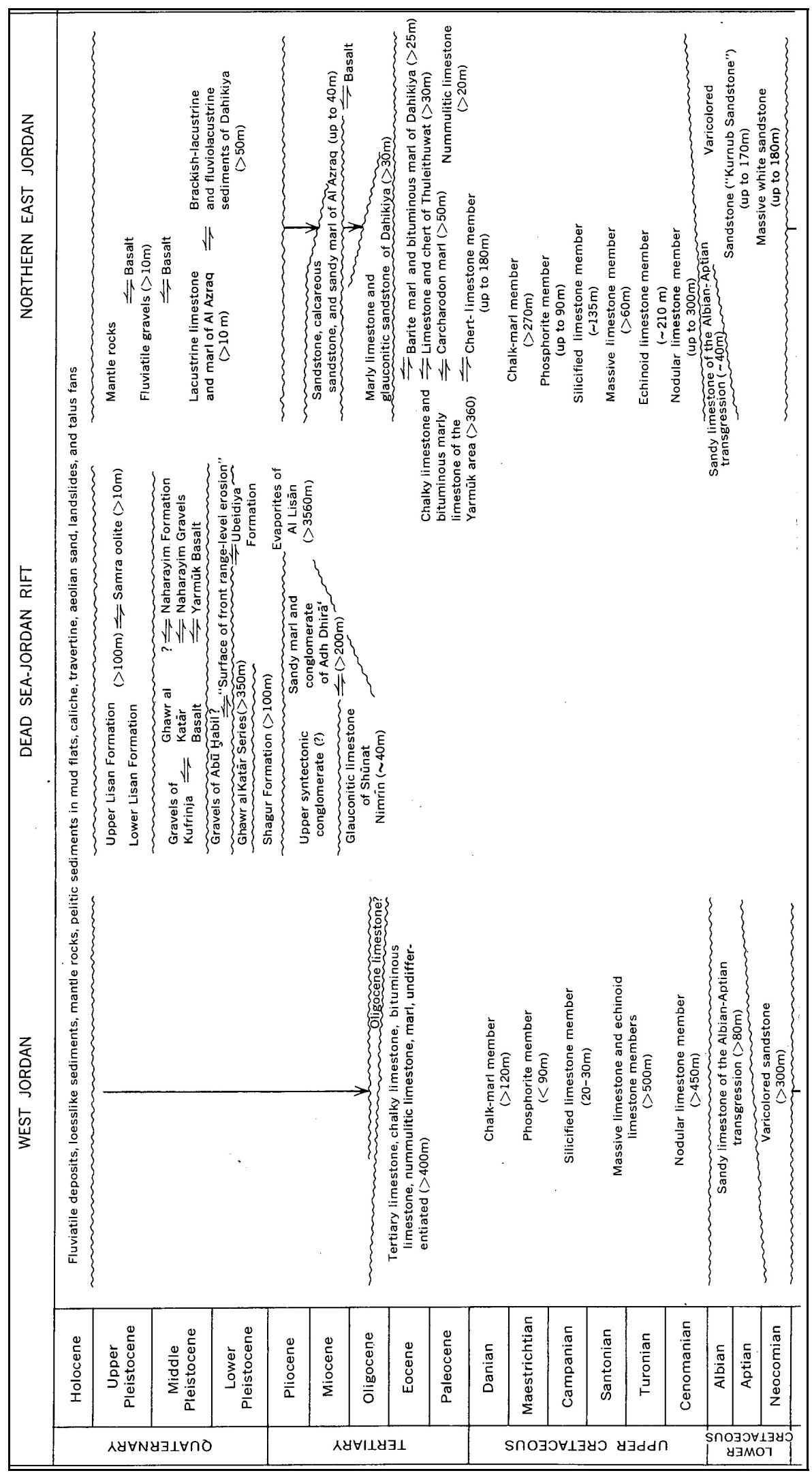

Figure 27. Stratigraphy and lithologic units from Miocene to the end of Holocene relating to north Jordan [16]. 


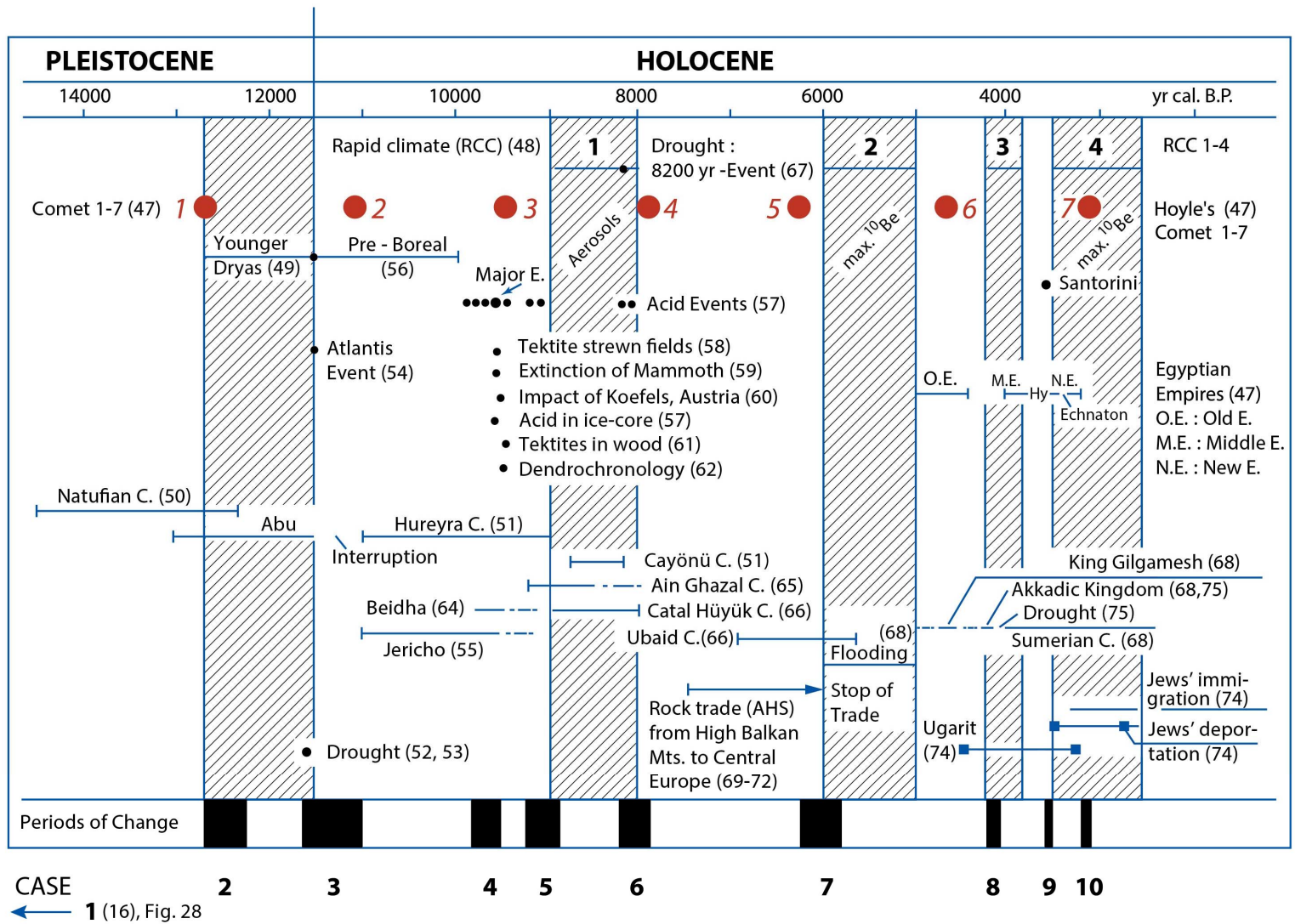

Figure 28. Compilation of: Rapid Climate Change (RCC) throughout Holocene [48]; Rise and fall of Neolithic/Bronze Age Cultures in the Near/Middle east [45] [55]; Diverse impact-related/impact-suspicious and other natural events and Time of relevance of a repeatedly returning Comet in our planetary system [47].

B.P.*, [60]), impact at Köfels, Austria $\left({ }^{14}\right.$ C: $9450 \mathrm{yr} \pm 150$ yr B.P.*, [61]), tektites in wood $\left({ }^{14} \mathrm{C}: 9530 \pm 200 \mathrm{yr}\right.$ B.P.*, [62]), and dendrochronological data $\left({ }^{14} \mathrm{C}: 9555 \pm 200\right.$ yr B.P.*, [63]), compilation of more references see [64].

Hoyle's Comet 3 coincides with the median value of the data provided above.

The Natufian Culture related to Jericho, also meets this time.

The Natufian sites of Beidha, Basta and Ba'ja located near of Petra, Jordan, brought evidence of cataclysm probably caused by earthquakes [65]. Furthermore, there is no doubt of abrupt fall of all cities in southern Jordan during the last third of the $8^{\text {th }}$ millennium cal. P.C. [65].

\subsection{Case 5}

After two acid events correlating with the end of the ABU HUREYRA CULTURE, the first Holocene RCC (9000 - 8000 yr. B.P.) presents a wide-spread significant climate change: ice-sheets were still existing in the Northern Hemisphere, ice-rafting, increased atmospheric circulation, glacier retreat in the European Alps, and frequent polar northwesterly outbreaks over the Aegean Sea were typical [49]. Summer monsoons over the Arabian Sea and precipitation increased in the Middle East. Under such favorable conditions, the Early Neolithic Ain GHAZAL CULTURE, Jordan [66], the CAYÖNÜ CULTURE, Turkey [52], and the CATAL HÜJÜK CULTURE, Turkey [67] developed in the Near East with the beginning of this first RCC that significantly reveals aerosols in contrast to the following RCCs [49].

\subsection{Case 6}

The early Neolithic Cultures mentioned under Case 5, disappeared at the end of the first RCC. There is an approximate coincidence of the so-called "8200 yr B.P. Event" [68], both acid events at 8200 and 8060 yr B.P. 
[58], and Hoyle's Comet 4 [48]. At low latitudes, the "8200 yr B.P. Event" provided widespread aridity (droughts) interrupting a long period of humidity while in high latitudes major ice-rafting, strengthened atmospheric circulation, and glacier advance in Scandinavia dominated [49].

\subsection{Case 7}

The second RCC (6000 - 5000 yr B.P.) reveals the co-occurrence of high latitude cooling and low latitude aridity in the Northern Hemisphere, while ice-rafting, alpine glacier advance and strengthened westerlies existed over the Atlantic, a long-term trend of increasing rainfall variability dominated the Near and Middle East.

Maxima of ${ }^{14} \mathrm{C}$ - and ${ }^{10} \mathrm{Be}$-data give a reliable evidence of solar output decline [49].

The Neolithic UBAID CULTURE, Mesopotamia appeared at 7000 yr B.P. [67] and ended more or less shortly after the beginning of the second RCC that may relate to extreme flooding throughout Mesopotamia having lasted about $1000 \mathrm{yr}[69]$.

A spectacular example of climate influence on human cultures is the end of export of excellent stone adze and axe raw material (AHS = actinolite-hornblende schist) from northwest Bulgaria (High Balkan Mts. and other related sites) to Central Europe [70]-[73]. The import started latest at $7500 \mathrm{yr} \mathrm{B.P.} \mathrm{and} \mathrm{ended} \mathrm{abruptly} \mathrm{at} \mathrm{about}$ 6200 - 6000 yr B.P. which means the beginning of the second RCC. Advance of glaciers across the alpine regions (High Balkan Mts., Carpathian Mts., European Alps) having worked as barriers, are definitely the reason for this abrupt export stop from southeast Europe. Very probably, the raw material source areas located at the southern slope of the High Balkan, may have been ice-covered.

Furthermore, the consequences of this hazardous climate change are to be found in a one thousand years lasting missing of cultural remnants in northwest Bulgaria [74] and by high differentiation of late Neolithic Cultures having lived north of the Alpine Mt. Belt. These cultures only used local raw materials like diabase, basalt, greywacke etc, exposed in Variscan basement formations localized north of the alpine barrier [70]-[73].

Hoyle's Comet 5 may be possibly taken into account as initiator of the second RCC.

\subsection{Interval: End RCC 2/Case 8 (5000 - 4000 yr B.P.)}

Immediately after the end of RCC 2, the Sumerian Culture developed in Mesopotamia, Iraq, where the Kingdom of Gilgamesh existed from 4750 - 4600 yr B.P.* [69], later followed by the Akkadic Kingdom under Sargon of Akkad (4340 - 4200 yr B.P.*) [69].

The "Gilgamesch Epos", as eldest written dating in "Cuneiform" character deals with the "Deluge" on claystone Tablet 11 [69]. It stems from the akkadic period. However, according to orientalists, the Epos was re-written several times prior to Tablet 11 [69]. Thus, precursors of the Epos hint on this hazardous event prior to King Gilgamesch, but obviously shortly after the catastrophic floodings between $6000-5000$ yr B.P. The following extract tells part of the Event [69, Transl.: Sch.].

"The weather looked terrible...The Annunaki raised up their torches to inflame the country by their horrible brightness... Because of Adad, the sky fell into oppression, all brightness changing in darkness...The country, the wide, broke like a pot...The southern storm blew for one day going to immerge the mountains into water...Like a battle to subject human beings...Nobody can sea each other...By this Deluge the deities frightened...Remained weeping...Six days and seven nights continues the wind, the Deluge, ... The hurricane eroded the country...On the approaching seventh day the hurricane stopped the Deluge...Calm and quiet was the sea...The bad hurricane stopped as did the Deluge...Looking around for one day there was silence...And mankind was completely transformed into soil".

One can read the evidence of wildfire [1], cataclysm [2], whirlstorm from south [3], erosion by tsunami [4], being close to the sea [5]. The setting was the lowland of Mesopotamia of both streams Euphrates and Tigris that was open to the Persian Gulf and to tsunamis. Thus, the source area of this hazardous event may have been situated in southeastern direction (Persian Gulf, Indian Ocean, Saudi Arabia).

The Old Empire of Egypt lasted throughout the interval 5000 - 4000 yr B.P. whose end coincided with the appearance of Hoyle's Comet 6 just at the same time when the UGARIT CULTURE [75] developed from a town located at the Mediterranean coast, Syria.

\subsection{Case 8}

The RCC 3 (4200 - 3800 yr B.P.) was less widespread. Generally speaking, it brought temperature fall in Eura- 
sia, glacier retreat in Europe, and arid conditions at lower attitudes with a distinct migration of the intertropical convergence zone [49].

The end of the AKKADIC CULTURE and the beginning of RCC 3 was originated by an extreme and long-lasting drought in the Near and Middle East [76]. It led to the collapse of this culture proven by an abrupt increase of $\delta^{18} \mathrm{O}$ in benthic foraminifera recovered from sediments of the Shaban Deep/Northern Red Sea.

The UGARIT CULTURE and the SUMERIAN CULTURE continued into the realm of RCC 4 after the drought when the Middle Empire of Egypt arose.

The interval between the Old and Middle Egyptian Empire coincides with the drought maximum, whereas the interval between Middle and New Empire coincides with the interval between RCC 3 and RCC 4 which is the time of Hyksos Invasion.

\subsection{Case 9}

The RCC 4 (3500 - 2500 yr B.P.) shows similar climate distribution patterns in the Northern Hemisphere like RCC 2. ${ }^{10} \mathrm{Be}$ - and ${ }^{14} \mathrm{C}$-data give evidence on a decline of solar output, too [49].

Its beginning coincides with the rise of the New Egyptian Empire, the Jews' immigration, and the outbreak of the mega-volcano of Santorini, Greece that exploded and threw out tremendous masses of ashes, also encountered in the Nile Delta, Egypt [77]. This challenges the idea that Pharao Echnaton initiated a religious revolution by replacing the former deities by the Sun (Aton) as the only God that appeared after a longer time of darkness by globally circulating ashes in the atmosphere and stratosphere. After Echnaton the former deities were re-introduced!

Modern excavations show amazing evidence on Echnaton's Amarna [PHOENIX TV-Transmission 2014, 6.7]. During this chaotic time, Amarna seemed a place of wealth and food abundance (i.e. 800 tables of sacrifice in the Aton-Temple), however it reveals suffering of population. There are clear indications on severe diseases like anemia, parasites infections, genetic defects (spinal cord) with an extremely high death rate $(60 \%$ children, $18 \%$ adults).

Echnaton's wife Nofretete disappeared in the 12th Century of reign, her daughter followed two years later. Echnaton died in the 17th year of rule, and his corpse was never found.

There is an extreme high probability to relate the hazardous New Egyptian Empire to the Santorini megaoutbreak ( $\sim 3640 \mathrm{yr}$ cal. B.P.) whose aerosols, ashes, acid pollution etc. brought unimaginable destruction and death over Egypt and the whole Mediterranean, see also [77] where all Biblical Plagues in the Nile Delta can be explained by effects of pumice ashes and relating pollution.

\subsection{Case 10}

After the UGARIT CULTURE had passed the RCC 3-period, it had its cultural climax and end about mid of the RCC 4 coinciding with Hoyle'S Comet 7. This culture used character-writing as precursor of the ancient Hebraic writing [75]. Thus, the Jews were in the position to receive information on hazards that occurred in the Near and Middle East from both SUMERIAN and UGARIT CULTURE. That could be an early source for "John's Apocalypse" [78].

The Jewish deportation by the Assyrians took place in 2587 yr B.P.* and might have been a delayed chance to be re-faced with the subject of "Deluge" [75].

Regarding the geoscientific phenomena discussed, there results a northwest/southeast-striking distribution pattern where RCCs and duration of Neolithic and Bronze Age Cultures offer a complex interchange.

On account of impact effects for the Neolithic and Bronze Age Cultures of the Near/Middle East, the temperature/time relationship of impact products is important for evaluation. According to data of the Chicxulub Impact which happened at the K/T-boundary in Yucatan, Mexico, there exist the following estimations: fall-back ejecta work hours to days. Ash, soot, and aerosols $\left(\mathrm{NO}_{\mathrm{x}}, \mathrm{SO}_{2}\right)$ remained weeks to decades circulating in the atmosphere and stratosphere causing a significant decrease of temperature (sintwinter). The green house effects mainly originated by $\mathrm{H}_{2} \mathrm{O}$ and $\mathrm{CO}_{2}$, endure over many decades or even longer, causing increasing temperatures ([78], Figure 29).

Concerning the frequency of impacts, there are some rough data available: impact craters like the Arizona Crater (1.6 kilometers in diameter), may be generated once per $1000 \mathrm{yr}$ [79]. Impactors of 50 - 300 meters in diameter may occur every $250 \mathrm{yr}$ [20]. At least four impacts excavating crater diameters of about 1 kilometer 


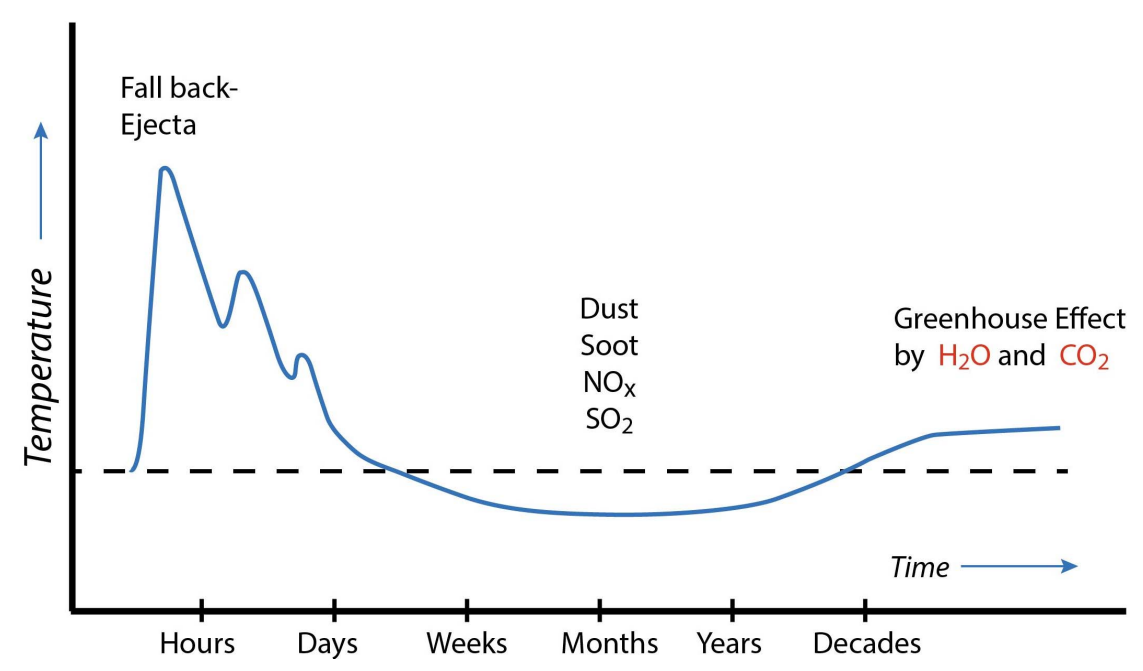

Figure 29. Evaluation of temperature change on Earth Surface after the Chicxulub Impact at the K/T-boundary relating to time [after 78].

are to be expected throughout the recorded human history [20]. Impact onto shelf platforms may generate Tsunami waves as high as the water depth (i.e. 150 meters in the North Sea) [20].

\section{Evidence of Impact Processes in Myths of the Near/Middle East}

"The intuitive spirit is a holy gift and the rational intellect his faithful servant. We have generated a society that adores the servant and has forgotten the gift".

Albert Einstein (Transl.: Sch.)

Compilations of three Austrian authors [62] [75] reveal an overwhelming abundance of myths of indigenous peoples around the globe that deal with the subject "Deluge". There exists adequate mythological information from all continents on this subject that it seems more than enough to restrict our focus only onto the Near/Middle East. Thus, the most informative source is the "Revelation of John" (Apocalypse) to be read in the New Testament of the Bible or in a rather modern translation, especially Chapters 6 - 16 [78], and in the Old Testament [1. and 2. Book, Mose].

In spite of the mythologic language, the text of the myths surprisingly appears realistic: starting with the observation of approaching extraterrestrial bodies, mentioning the impact, the following earthquakes and faulting, super cyclonic whirlstorms (wildfires), the effect of hot/melted ejecta over long distances, destruction of fauna and flora (including human beings and cities), and finally long-lasting flooding, darkness as well as environmental pollution, as follows (Transl.: H.P. Koch, Sch.).

\subsection{Observation of the Approaching Impactor}

"....and the stars in the sky fell to Earth, as late figs drop from a fig-tree when shaken by a strong wind" [Apc. $6,13]$. "Then I saw another mighty angel coming down from Heaven,... His face was like a sun, and his legs were like fiery pillars" [Apc. 10, 1].

"A giant star, blazing like a torch, fell down from Heaven, on one third of the rivers and on the springs of water" [Apc. 8, 10]. "A gigantic mountain looking like a huge rock boulder, that burst in fire storms..." [Apc. 8, 8].

For further reading, the "Revelation of John" points generally to seven major "trumpets" (extraterrestrial bodies), in every case accompanied by a "firework" of smaller fragments.

\subsection{The Impact}

"But then, the angel took the pan, filled it with glowing fire from the altar, threw it to the ground. What a noise and quaking" [Apc. 8,5].

"... as this star received a key that opened the door to the springs of the abyss. Smoke ascended from the spring, 
so as coming through the chimney of a gigantic furnace, and darkening the sun and the sky...” [Apc. 9, 1-2].

".... and that happened at the hour when the earth commenced to quake. One tenth of all houses broke down, 7000 people were killed...” [Apc. 11, 13].

"...thunder noise and a tremendous earthquake occurred, as has never been since human beings live on earth..." [Apc. 16, 18].

"The islands changed their position, coastlines disappeared, mountains were never found" [Apc. 16, 20].

Referring these quotations of the Apocalypse to our field experience along the "Avenue of Ricochet-ImpactThermo-Cataclysm", the consequences of the impact are documented by: 1) The typical features of shock metamorphism (like shatter cones), the brecciation of the "Mottled Zones" of Jordan and Palestine, the disharmonic folding of the Upper Cretaceous Silicified Limestone Unit of northwestern Jordan, and finally the reactivation of the pre-impact fault system and the formation of horizontal stylolites as well as lateral slicken sides on faults and joints.

\subsection{Super-Cyclonic Whirlstorms and Heat Storms}

"A third of the Earth was burnt up, a third of the trees was burnt up, and all the green grass was burnt up..." [Apc. 8, 7]..."to let human beings burn. They dried out in the heat..." [Apc. 16, 8].

This heat storm brought temperature conditions of the Sanidine-Hornfels-Facies over the Upper Cretaceous bituminous marlstones and limestones in the "Mottled Zone". Even the melting of diverse ores at temperatures of more than $1100^{\circ} \mathrm{C}$ should be taken into account as ancient Persians surrender: "All the metal from the mountains has been molten and it flowed down over the Earth as glowing stream" (Ziegler and Oppenheim 1921, [62]).

\subsection{Ejecta}

"... and a gigantic hail including boulders of hundred weight came down from heaven over human beings..." [Apc. 16, 21].

"... and out of the soot fell grasshoppers, giant vermin, down to Earth"...[Apc. 9, 3]..."The bodies of the grass-hoppers looked like the bellies of wild horses that rush into a battle" [Apc. 9, 7].

"...Red and black dust like the soot from the furnice was raised over the whole land of Egypt" ... "and the worst hailstorm that has ever fallen on Egypt" ... "The stones that fell upon Egypt were hot ... Hail and fire were intermingled..." ... "The hail was accompanied by a rolling thunder, and it smashed every thing that was in the open country, every man and animal and every thing growing in the field, and it stripped every tree" [2. Mose, Ch. 9, 23 - 25].

"...out of their mouths came fire, sulfur and smoke, all of them raging on Earth and snatching away one third of mankind. Burnt! Etched! Suffocated!" [Apc. 9, 17-18].

Up to now, ejecta have only been found at the Ring Structure of Jebel Waqf as Suwwan as fall-back and as fall-out close to the crater rim. But there is more ejected material to be expected in the realm of the "Avenue of Ricochet-Impact-Thermo-Cataclysm" and Ricochet-Impact-Thermo-Cataclysm in northeastern Jordan. Furthermore, we expect impact material intercalated with Pleisto-/Holocene sediments within the Jordan Rift System.

\subsection{Explosive Ascent of Groundwater}

“...break up all springs of the deep abyss..." [1. Mose, Ch. 7, 11].

“... at this hour the Lord opened the springs of the abyss" (Gorion, 1913).

This process is realized by the widespread travertines overlying the marbles of the Jordanian "Mottled Zone", i.e. at Jizha (Figures 13-15).

\subsection{Acid Rain and Environmental Pollution}

“...Jehova let rain down burning sulfur on Sodom and Gomorrah out of the Heaven. Thus he overthrew these cities and the entire plain, and also the vegetation in the land, and he saw dense smoke rising from the land like from a furnice" [1. Mose, Ch. 19, 24-25].

"... and a rain came on earth 40 days and 40 nights" [1. Mose, Ch. 7, 12].

"....and the water became abundant and grew up so much on Earth that all high mountains were covered be- 
neath the whole sky" [1. Mose, Ch. 7, 19].

“....and oh, Heaven keep back your rain" [Koran, 11, 45].

The biblical quotations cited above, appear surprisingly realistic, despite of their mythologic terminology. They represent prehistoric sources orally surrendered down to the first Sumerian writing of Cuneiform character in the Gilgamesch Epos. The observers of the hazardous Apocalypse did obviously not have a vision directing into future, they describe realistic impact processes on Earth and relating consequences in the language of their time and ethnologic position.

Comparing the high number ( 180) of "Deluge" sources [62] [75], the same substantial contents of tremendous hazards are significant through all of them. See also i.e. Figure 30 from Aztec Mythology.

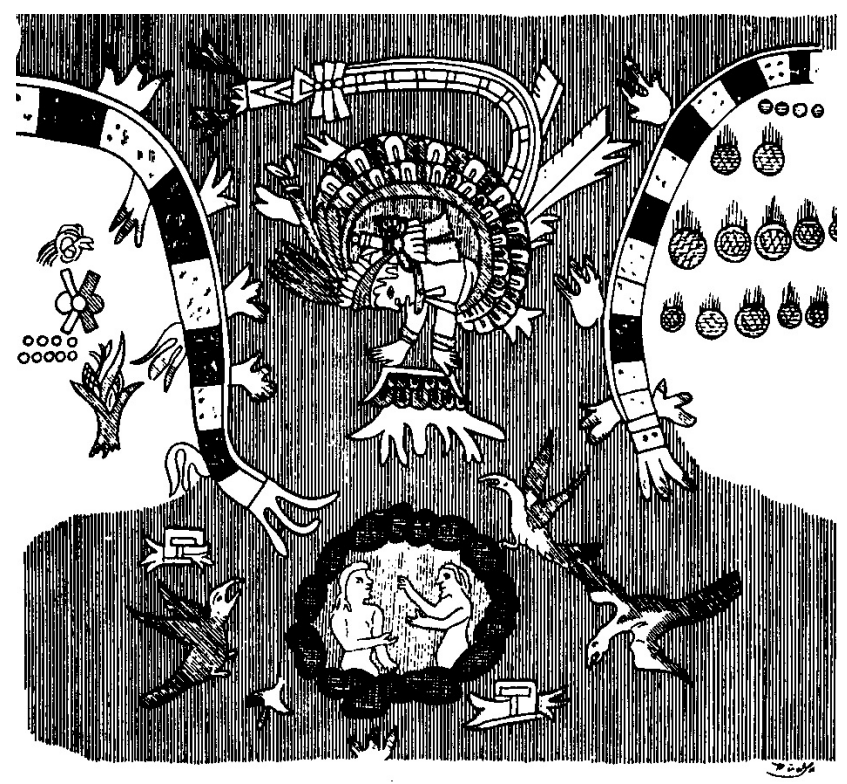

(a)

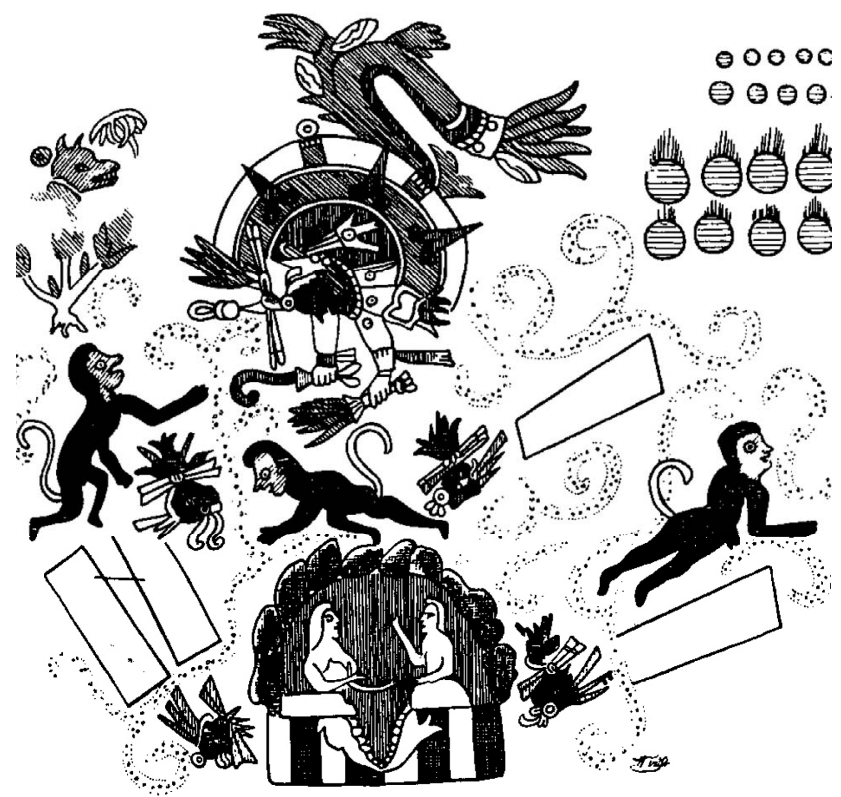

(b)

Figure 30. Whirlstorm (a) initiated by an impact event (b) in the myths of the Aztecs. Rescue of people by escape into caves. Codex Vaticanus, No. 3738, Fol. 6, resp. 6 verso, from [61]. 
It is amazing how human spirit diverges in the interpretation of "John's Revelation". So the German theologian and psychotherapist Drewermann [80] stress the necessity of psychological interpretation. He brought the processes described in Chs. Apc, 6-16 in connection with human psychic suffering, guilt, and anxiety relating to own moral weakness and "fall of man" as well as with the Roman occupation. A similar way of psychologic-philosophical interpretation was given by Ellul [81].

According to the frequency of impacts on Earth [20], there cannot be any doubt that all "Deluge" reports are based on a remarkably high unknown number of "Rare Events" as postulated in this paper.

\section{Conclusions}

"The recognition of the sedimentologic consequences of 'Convulsive Events' poses a special challenge to Sedimentary Geologists. Meeting this challenge will almost certainly demonstrate that 'Convulsive Geologic Events' have greater relevance to the sedimentary record than has been previously recognized.

Why there is no physical evidence for such impacts other than the Cretaceous-Tertiary boundary clay? Part of the problem undoubtedly lies with preservation.

But the effects of major impacts are likely to be of such broadly regional, even global, extent that one would intuitively expect at least fragmentary preservation of its consequences." [82].

Since the supplementary data of JWS Impact Structure reconfirm the melting of the top parts of the Lower Cretaceous Kurnub-Sandstone (above $1714^{\circ} \mathrm{C}$ ), the cooling down process could be verified via all $\mathrm{SiO}_{2}$-modifications to low temperature $\beta$-quartz. Core-drilling is to be recommended between Central Uplift and Inner Ring in hoping on recovery of chert glass and sandstone-derived glass for fission tracking the impact age.

Regarding the primary total sedimentary sequence of the target area it makes evident that a gigantic volume of carbonate rocks had been vaporized (above $870^{\circ} \mathrm{C}$ ), thus excavation analysis only relates to the different phases of chert and Kurnub-Sandstone (see i.e. "Chert-Carbonate-Impact-Chess Game").

Evidence of highest temperature mineral neoformations (up to $1200^{\circ} \mathrm{C}$ ) verifies the "Mottled Zone" of Jordan and Israel as an area of Ricochet-Impact-Thermo-Cataclysm.

In a scenario: "Impacting Meets Plate Tectonics", the Jordan Rift System cannot be totally excluded as motor for north-northeast-striking disharmonic folding and the evidence of horizontal stylolites hosted in Upper Cretaceous carbonate rocks of the Western Mountain Range east of the Rift system (Figures 31(a)-(b)). Like the Palmyrian fold system, the folds fit to the transpressional features of the Rift System as the transtensional Dead Sea and Lake Tiberias pull-apart basins do. However, the west-northwest-verging folds rather indicate the energy impulse area in the east-southeastern parts of the Saudi Arabian Craton.

Accepting an analytical error of \pm 100 yr for ${ }^{14} \mathrm{C}_{\text {cal }}$ B.P. measurements, there appears an amazing abundance of approximate coincidences of the parameters applied:

a) Hoyle's Comet re-events correlate with RCCs.

b) RCCs correlate with Rise and Fall of Neolithic/Bronze Age Cultures in the Near/Middle East.

c) Aerosols verified through RCC 1, obviously relate to preceding acid events (major event $\sim 9640$ yr B.P.*).

d) RCC 2, 4 correlate with periods of decreasing solar activity $\left({ }^{10} \mathrm{Be}\right)$.

e) Tektite ages coincide with Mammoth extinction, Köfels Impact, Austria, acid in ice cores, and hazardous events at Natufian sites of Jericho, West-Bank, Beidha, Basta, Ba'ij and all other cities in Southern Jordan.

f) Santorini outbreak, Aegean Sea (3627 - 3600 yr B.P.*) coincides with the beginning of RCC 4 and with the end of Hyksos rule in Egypt, probably initiating the religious revolution by Echnaton (3364 - 3347 yr B.P.*). He replaced the traditional deities by the Sun (Aton) as only God after a long period of darkness caused by circulating ashes and aerosols in the stratosphere and atmosphere.

g) Stop of rock trade (AHS = actinolite-hornblende schist, most valuable raw material for stone axes) from the High Balkan Mts. to Central Europe because of glacier advance in the source areas. Contemporaneous hazardous flooding events (Deluge?) in the Near/Middle East, Mesopotamia.

h) Droughts (Case 2, 3,8) led to the extinction of early Neolithic Cultures and of the Akkadic Kingdom, Mesopotamia as well.

General statement: Hoyle's repeatedly returning Comet (1 - 10) and following relating RCCs mostly directed Rise and Fall of Neolithic/Bronze Age Cultures.

As the "Gilgamesh Epos" and "John's Revelation" reveal, these myths provide realistic information of processes which happened in Nature and are worthy to be taken as seriously by modern scientists. The myths' 


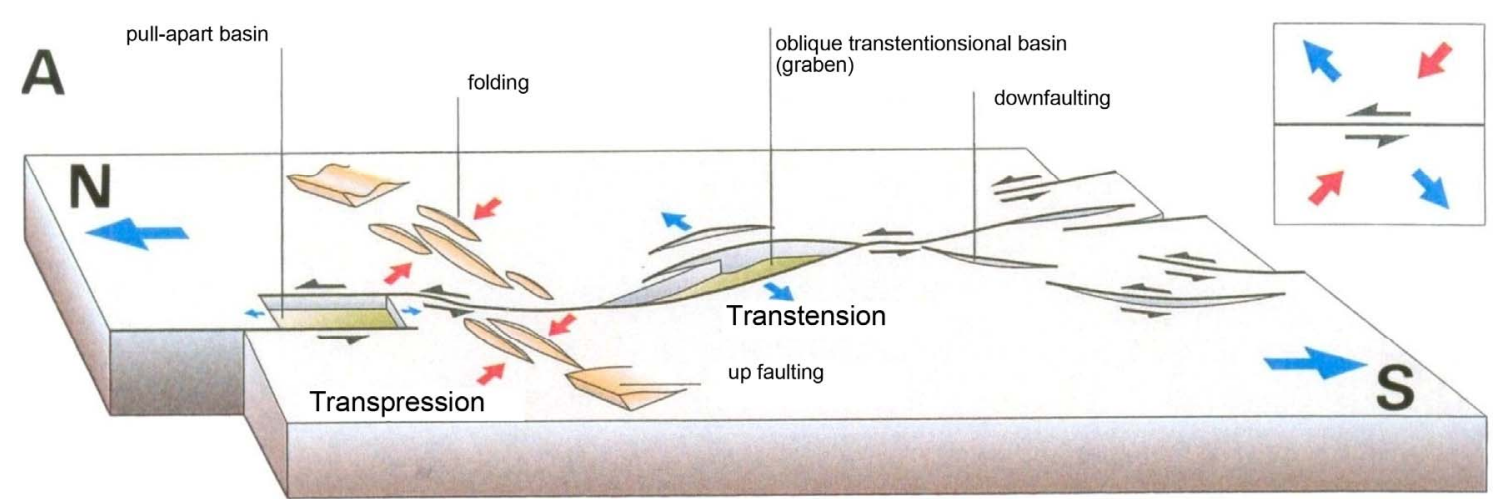

(a)

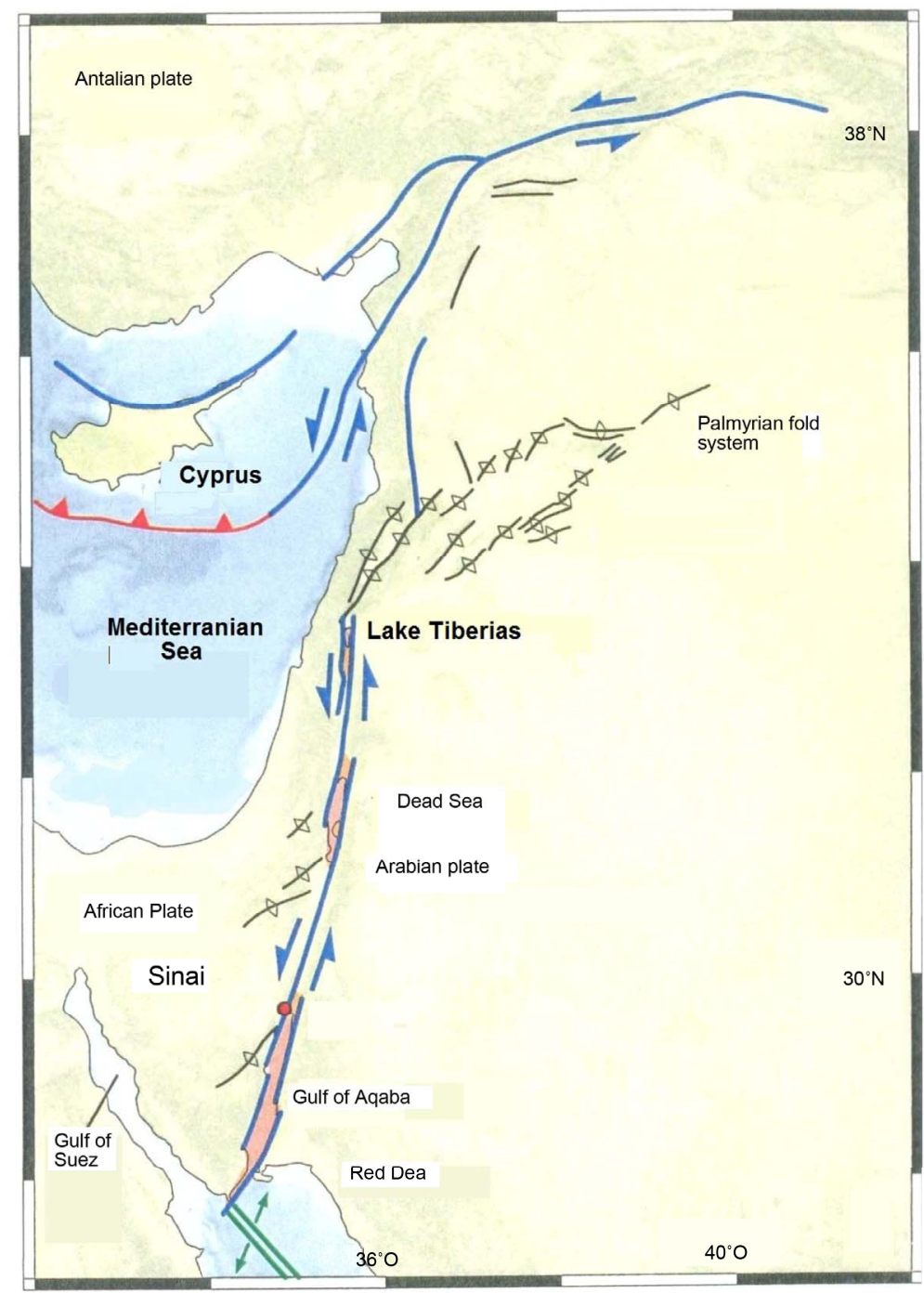

(b)

Figure 31. The Jordan Rift System [after: 19]. (a) Schematic block diagram of the left-sided transform fault showing transtensional structures like pull-apart basins (Dead Sea, Lake Tiberias) as well as transpressional structures like folding, downand upfaulting. (b) The Jordan Rift System mediates between the Red Sea and the Cyprus subduction zone. Transtensional pull-apart basins and transpressional folding zones like the Palmyrian System and subordinate disharmonic folds within the Upper Cretaceous carbonate rocks of the Western Mountainous Range of Jordan have been originated along the major transform fault. The movement between the Arabian Plate and the African Plate amounts up to $\sim 1$ centimeter/year [19]. 
contents are $\mathrm{x}$-fold reconfirmed and handed down by other $\sim 180$ ethnic peoples around the globe [62] [75].

According to the data submitted, possible impact events of high probability may have occurred around 9640 yr B.P.* and $\sim 6000 \mathrm{yr}$ B.P.* "Rare Events" of lower probability might have happened in Case 6 ( $\sim 8000 \mathrm{yr}$ B.P.) and in Case $10(\sim 3200$ yr B.P.).

Most of all uncommon geologic phenomena across Jordan and adjacent areas genetically fit together and realize more or less an "Impact Ensemble" originated by an unknown number of "Rare Events".

\section{Closing Statement}

"The distortion of the view of sight owning the disciplinary scholar does not only consist on methodological or substantial one-sidedness, ... but also in a methodological refuse applied to transitional phenomena."

The drawer principle-the black/white painting-is therefore not adequate to meet the challenges of present time. If there is a "Science of Effects at the Whole", there will be a need to be a science of recording such transitional phenomena.

"In that lies an important criterion for interdisciplinary research". (A.M.K. Müller [83], Transl. Sch.)

Since the pull-apart basins of the Jordan Rift System host some 6000-meter-thick Cenozoic sediments (mostly evaporites), which represent excellent traps for volcanic and impact ejecta and ashes, core-drilling of the Dead Sea pull-apart basin would be an endeavor of challenge in modern Geosciences, apart from the former well Al Lisan-1 [84].

\section{Acknowledgements}

Many thanks are addressed to Prof. Dr. H. Khoury, University of Jordan, Amman, who introduced us to the "Mottled Zone" of Jordan at a quarry near Jizha, Central Jordan.

\section{References}

[1] Salameh, E., Khoury, H. and Schneider, W. (2006) Jebel Waqf as Suwwan, Jordan: A Possible Impact Crater-A First Approach. Zeitschrift der Deutsche Gesellschaft für Geowissenschaften, 157, 319-325. http://dx.doi.org/10.1127/1860-1804/2006/0157-0319

[2] Salameh, E., Khoury, H., Reimold, W.U. and Schneider, W. (2008) The First Large Meteorite Impact Structure Discovered in the Middle East: Jebel Waqf as Suwwan, Jordan. Meteoritics \& Planetary Science, 43, 1681-1690.

[3] Salameh, E., Khoury, H., Reimold, W.U., Schneider, W. and Kenkmann, T. (2008) First Large Meteorite Impact Structure Discovered in the Middle East: Jebel Waqf as Suwwan, Jordan. The 4th Conference on Large Meteorite Impacts and Planetary Evolution, Parys, 17-21 August 2008, LPI Contribution No. 1423, Paper ID: 3106.

[4] Kenkmann, T., Khirfan, M., Reimold, W.U., Salameh, E., Konsul, K. and Khoury, H. (2009) The Structure of the Jebel Waqf as Suwwan Impact Crater, Jordan, as Revealed from Field Analysis, Remote Sensing Mapping, and Interpretation of Geophysical Data. The 1st Arab Impact Cratering and Astrogeology Conference, Amman, 9-11 November 2009, 32-37.

[5] Gretener, P.E. (1978) Reflexions on the "Rare Event" and Related Concepts in Geology. University of Calgary, Calgary, $17 \mathrm{p}$.

[6] Sagan, C. (1977) An Analyses of a World in Collision. In: Goldsmith, D.W., Ed., Scientists Confront Velikovsky, Cornell University Press, Ithaca, 45.

[7] Heimbach, W. (1970) Zur Geologie Nordost-Jordaniens. Geologisches Jahrbuch, 88, 265-288.

[8] Heimbach, W. (1971) Die Strukturen von Zakimat al Hasa, Ostjordanien, ihre Stellung im Regionalen Strukturplan and zum Vorkommen von Barytrosen. Geologisches Jahrbuch, 89, 329-338.

[9] Mitchel, R. (1958) The Al Umchaimin Crater, Western Iraq. Geographical Journal, 124, 578-580.

[10] Yaghan, R. and Mikbel, S. (1985) Geologic and Structural Interpretation of Landsat-Images in North Jordan, Proceedings of 2nd Jordanian Conference, Amman, 22-24 April 1985, 466-495.

[11] Ruef, M. (1967) Zur Stratigraphie und Tektonik der Kreide Jordaniens, mit einem Beitrag zur Genese gefalteter Kieselgesteine. Dissertation, Universität Heidelberg, Heidelberg, 140 p.

[12] Salameh E. and Zacher W. (1982) Horizontal Stylolites and Paleostress in Jordan. Neues Jahrbuch für Geologie und Paläontologie, 8, 509-512.

[13] Mikbel, S. and Zacher, W. (1986) Fold Structures in Northern Jordan. Neues Jahrbuch für Geologie und Paläontologie, 4, 248-256. 
[14] Heimbach, W. and Roesch, H. (1980) Die "Mottled Zone" in Zentraljordanien. Geologisches Jahrbuch, 40, 3-17.

[15] Gross, S. (1970) Mineralogy of the "Mottled Zone" Complex in Israel. List of Minerals. Israel Journal of Earth Science, 19, 211-216.

[16] Bender, F. (1975) Geology of the Arabian Peninsula, Jordan. Geological Survey Professional Paper 560-I. United States Government Printing Office, Washington DC, 11-136.

[17] Reimold, W.U. (2007) Revolutions in the Earth Sciences: Continental Drift, Impact, and Other Catastrophes. South African Journal of Geology, 110, 1-46. http://dx.doi.org/10.2113/gssajg.110.1.1

[18] Master, S. (2009) Wadi El Murbah, A Possible 7.5 Kilometer-Diameter Buried Impact Structure on the Jordan/Iraq Border: Geological Setting and Remote Sensing. The 1st Arab Impact Cratering and Astrogeology Conference, Amman, 9-11 November 2009, Abstract Volume, 58-60.

[19] Frisch, W. and Meschede, M. (2009) Plattentektonik, 3. Auflage. Primus-Verlag, Darmstadt, 196 p.

[20] Price, N.J. (2001) Major Impacts and Plate Tectonics. Routledge, London, 354 p.

[21] Steinitz, G. (1981) Enigmatic Chert Structures in the Senonian Cherts of Israel. First Geological Survey Bulletin, 75, 1-46.

[22] Wiesemann, G. (1969) Zur Tektonik des Gebietes östlich des Grabenabschnitts Totes Meer-Jordantal. Beihefte Geologisches Jahrbuch, 81, 215-247.

[23] Sander, B. (1948) Einführung in die Gefügekunde der Geologischen Körper. Springer-Verlag, Wien, 215 p.

[24] Hiller, W. and Schneider, G. (1967) Geophysik. In: Brinkmann, R., Ed., Lehrbuch der Allgemeinen Geologie, Band 3 , Enke, Stuttgart, 396-547.

[25] David, E. (1969) Das Ries-Ereignis als physikalischer Vorgang. Geologica Bavarica, 61, 350-378.

[26] Anvimelech, M. (1964) Remarks of the Occurrence of Unusual High-Temperature Minerals in the So-Called "Mottled Zone" Complex of Israel. Israel Journal of Earth Science, 13, 102-110.

[27] Bentor, Y.K., Gross, S. and Heller, L. (1963) High-Temperature Minerals in Non-Metamorphosed Sediments in Israel. Nature, 199, 478-479. http://dx.doi.org/10.1038/199478a0

[28] Kolodny, Y. and Gross, S. (1974) Thermal Metamorphism by Combustion of Organic Matter: Isotopic and Petrological Evidence. The Journal of Geology, 82, 489-506. http://dx.doi.org/10.1086/627995

[29] Kolodny, Y., Bar, M. and Sass, E. (1971) Fission Track Age of the "Mottled Zone" Event in Israel. Earth and Planetary Science Letters, 11, 269-272. http://dx.doi.org/10.1016/0012-821X(71)90178-6

[30] Winkler, H.G.F. (1965) Die Genese der Metamorphen Gesteine. Springer, Heidelberg, 218 p. http://dx.doi.org/10.1007/978-3-662-29030-9

[31] Schultz, P.H. and Gault, D.E. (1990) Prolonged Global Catastrophes from Oblique Impacts. Geological Society America Special Papers, 247, 239-262.

[32] Gilmour, I., Wolbach, W.S. and Anders, E. (1990) Major Wildfires at the Cretaceous/Tertiary Boundary. In: Clube, S.V.M., Ed., Catastrophes and Evolution: Astronomical Foundations, Cambridge University Press, Cambridge, 195212.

[33] Melosh, H.J., Schneider, N.M., Zahnle, K.J. and Latham, D. (1990) Ignition of Global Wildfires at the Cretaceous/ Tertiary Boundary. Nature, 343, 251-254. http://dx.doi.org/10.1038/343251a0

[34] Napier, W.M. (1990) Terrestrial Catastrophism and Galactic Cycles. In: Clube, S.V.M., Ed., Catastrophes and Evolution: Astronomical Foundations, Cambridge University Press, Cambridge, 133-167.

[35] Rampino, M.R. and Stothers, R.B. (1984) Geological Rhythms and Cometary Impacts. Science, 226, 1427-1431. http://dx.doi.org/10.1126/science.226.4681.1427

[36] Thorson, R.M., Clayton, W.S. and Seeber, L. (1986) Geologic Evidence for a Large Prehistoric Earthquake in Eastern Connecticut. Geology, 14, 463-467. http://dx.doi.org/10.1130/0091-7613(1986)14<463:GEFALP>2.0.CO;2

[37] Hollemann, A. F., and Wiberg, E. (1964) Lehrbuch der Anorganischen Chmie. Walter de Gruyter \& Co., Berlin, 766 p.

[38] Khoury, H., Salameh, E. and Clark, I. (2014) Mineralogy and Origin of Surficial Uranium Deposits Hosted in Travertine and Calcrete from Central Jordan. Applied Geochemistry, 43, 49-65. http://dx.doi.org/10.1016/j.apgeochem.2014.02.005

[39] Gentner, W. and Wagner, G.A. (1969) Altersbestimmungen an Riesgläsern und Moldaviten. Geologica Bavarica, 61, 296-303.

[40] Tröger, W.E. (1969) Optische Bestimmung der Gesteinsbildenden Minerale Teil 2: Textband. Schweizerbart, Stuttgart, $822 \mathrm{p}$.

[41] Stöffler, D. (1971) Coesite and Stishovite in Shocked Crystalline Rocks. Journal of Geophysical Research, 76, 54745488. http://dx.doi.org/10.1029/JB076i023p05474 
[42] Von Engelhardt, W., Stöffler, D. and Schneider, W. (1969) Petrologische Untersuchungen im Ries. Geological Bavarica, 61, 229-295.

[43] Von Engelhardt, W. (1990) Distribution, Petrography and Shock Metamorphism of the Ejecta of the Ries Crater in Germany-A Review. Tectonophysics, 171, 259-273. http://dx.doi.org/10.1016/0040-1951(90)90104-G

[44] Salameh, E., Khoury, H. and Reimold, W.U. (2014) Drilling the Waqf as Suwwan Impact Structure. International Journal of Earth Sciences (Geologische Rundschau), 103, 253-264.

[45] Heimbach, W. (1969) Vulkanogene Erscheinungen in der Kalktafel Zentraljodaniens. Beihefte Geologisches Jahrbuch, 81, 149-160.

[46] Palmqvist, L. (2004) Der Grosse übergang, 10000 vor Christus bis 4000 vor Christus, Die Ersten Bauern der Westlichen Welt. In: Burenhult, G., Ed., Menschen der Urzeit, Karl Müller, Köln, 229-250.

[47] Wynn, J.C. and Shoemaker, E.M. (1998) The Day the Sands Caught Fire. Scientific American, 279, 36-45.

[48] Hoyle, F. (1993) Origin of the Universe and Origin of Religion. Moyer Bell Ltd., London, 135 p.

[49] Mayewski, P.A., Rohling, E.E., Stagerc, J.C., Karlénd, W., Maascha, K.A., Meeker, L.D., et al. (2004) Holocene Climate Variability. Quaternary Research, 62, 243-255. http://dx.doi.org/10.1016/i.yqres.2004.07.001

[50] Chappellaz, J., Blumier T., Raynaud, D., Barnola, J.M., Schwander, J. and Stauffert, B. (1993) Synchronos Changes in atmospheric CH4 and Greenland Climate between 40 and 8 kyr BP. Nature, 366, 443-445. http://dx.doi.org/10.1038/366443a0

[51] Da Costa, K. (2004) Die Natuf-Periode: Anfänge sesshaften Lebens. In: Burenhult, G., Ed., Menschen der Urzeit, Karl Müller, Köln, 234-236.

[52] Rowley-Conwy, P. (2004) Abu Hureyra: Die Ersten Bauern der Welt. In: Burenhult, G., Ed., Menschen der Urzeit, Karl Müller, Köln, 239.

[53] Schöll, M. and Risch, H. (1976) Oxygen and Carbon Isotope Analysis on Planktonic Foraminifera of Core 01-188 P (Southern Red Sea). Geologisches Jahrbuch, 17, 15-32.

[54] Friedman, G.M. (1972) Significance of Red Sea in Problem of Evaporites and Basinal Limestones. Bulletin American Association Petroleum Geology, 56, 1072-1086.

[55] Platon, A. (1994) Sämtliche Werke 04. Timaios, Kritias, Minos, Nomoi. Rowohlt, Reinbek.

[56] Palmqvist, L. (2004) Die ersten Bauern der Westlichen Welt. In: Burenhult, G., Ed., Menschen der Urzeit, Karl Müller, Köln, 229-232.

[57] Arz, H.W., Lamy, F., Pätzold, J., Müller, P.J. and Prins, M. (2003) Mediterranean Moisture Source for an Early Holocene Humid Period in the Northern Red Sea. Science, 300, 118-121. http://dx.doi.org/10.1126/science.1080325

[58] Hammer, C. U., Clausen, H.B. and Dansgaard, W. (1980) Greenland Ice-Sheet Evidence of Post-Glacial Volcanism and its Climatic Impact. Nature, 288, 230-235. http://dx.doi.org/10.1038/288230a0

[59] Glass, B.P. (1978) Austral-Asian Microtectites and the Stratigraphic Age of the Australites. Geological Society American Bulletin, 89, 1455-1458. http://dx.doi.org/10.1130/0016-7606(1978)89<1455:AMATSA>2.0.CO;2

[60] Dubrovo, I. (1990) The Pleistocene Elephants of Siberia. In: Agenbroad, L.D., Ed., Megafauna and Man, University Flagstad Press, 1-8.

[61] Surenian, R. (1989) Shock Metamorphism in the Koefels Structure. Abstracts and Program for the 52nd Annual Meeting of the Meteoritic Society, Vienna, 31 July-4 August 1989, 234.

[62] Tollmann, A.E. (1993) Und die Sintflut gab es doch-Vom Mythos zur Historischen Wahrheit. Droemer Knaur, München, $560 \mathrm{p}$.

[63] Suess, H.E. (1988) Radiocarbon in Tree Rings. In: Castagnoli, G.C., Ed., Solar-Terrestrial Relationships and the Earth Environment in the Last Millenia, Societa Italia Fisica, Bologna, 135-143.

[64] Koch, H.P. (2000) The Deluvian Impact. Peter Lange, Berlin, 274 p.

[65] Gebel, H.G.K. (2004) Central to What? The Centrality Issue of the LPPNB Mega-Site Phenomenon in Jordan. In: Bienert, H.-D., Gebel, H.G.K. and Neef, R., Eds., Central Settlements in Neolithic Jordan: Proceedings of a Symposium, Wadi Musa, 21-25 July 1997, 1-19.

[66] Rollefson, G.O. (2004) Ain Ghazal: Die groesste Bekannte Neolithische Siedlung. In: Burenhult, G., Ed., Menschen der Urzeit, Karl Müller, Köln, 248-250.

[67] Palmqvist, L. (2004) Kulte bei Catal Hüyük. In: Burenhult, G., Ed., Menschen der Urzeit, Karl Müller, Köln, $242-247$.

[68] Alley, R.B., Mayewski, P.A., Sowers, T., Stuiver, M., Taylor, K.C. and Clark, P.U. (1997) Holocene Climatic Instability: A Prominent Widespread Event 8200 Years Ago. Geology, 25, 483-486. http://dx.doi.org/10.1130/0091-7613(1997)025<0483:HCIAPW >2.3.CO;2 
[69] Schott, A. (1934) Das Gilgamesch-Epo. Philipp Reclam Junior, Stuttgart, No. 7235 (2), 122 p.

[70] Schwarz-Mackensen, G. and Schneider, W. (1983) Woe liegen die Hauptliefergebiete für das Rohmaterial donauländischer Steinbeile und-äxte in Mitteleuropa? Archäologisches Korrespondenzblatt, 13, 305-314.

[71] Schwarz-Mackensen, G. and Schneider, W. (1986) Petrographie und Herkunft des Rohmaterials neolithischer Steinbeile und-äxte im Nördlichen Harzvorland. Archäologisches Korrespondenzblatt, 16, 29-44.

[72] Schwarz-Mackensen, G. and Schneider, W. (1987) The Raw Material of Neolithic Adzes and Axes in Central Europe: Petrography and Provenance. Antiquity, 61, 66-69.

[73] Schwarz-Mackensen, G. and Schneider, W. (2012) Felsgesteine als Rohmaterial neolithischer Steinbeile und-äxte in Mitteleuropa. In: Floss, H., Ed., Steinartefacts—Vom Altpaläolithikum bis in die Neuzeit, Kerns Verlag, Tübingen, 875-892. http:/www.booklooker.de/app/result.php?page=1\&recPerPage $=10 \&$ setMediaType $=0 \&$ autor=Drewermann $\% 2 \mathrm{C}+$ Euge $\underline{n} \&$ titel $=$ Tiefenpsychologie + und + Exegese + Band $+I I \& \&$ sortOrder=preis total

[74] Todorova, H. (2009) Oral Communication, Academy of Science, Sofia, Bulgaria.

[75] Koch, H.P. (2000) Sintflut: Die Bibel berichtet von der Urkatastrophe der Menschheit. Verlag Kremayr \& Scheriau, Wien, $336 \mathrm{p}$.

[76] Arz, H.W., Lamy, F. and Pätzold, J. (2006) A Pronounced Dry Event Recorded around 4.2 ka in Brine Sediments from the Northern Red Sea. Quaternary Research, 66, 432-441. http://dx.doi.org/10.1016/j.yqres.2006.05.006

[77] Santorini and Its Eruption in the Late Bronze Age. http://de.wikipedia.org/wiki/Minoische Eruption

[78] Jens, W. (1987) Das A und das O (Die Offenbarung des Johannes). Radius-Verlag, Stuttgart, 93 p.

[79] Stöffler, D. (2002) Betrothing aus dem Weltall-Asteroiden und Kometen. In: Emmermann, R., Ed., An den Fronten der Forschung, Verhandlungen der Gesellschaft Deutscher Naturforscher und Ärzte 122. Versammlung. Halle, 81-98.

[80] Drewermann, E. (1992) Tiefenpsychologie und Exeges, Band 2. Walter-Verlag, Olten und Freiburg im Breisgau, 851 p.

[81] Ellul, J. (1981) Apokalypse. Die Offenbarung der Johannes-Enthüllung der Wirklichkeit. Neukirchener Verlag, Neukirchen-Vluyn, $263 \mathrm{p}$.

[82] Clifton, H.E. (1988) Sedimentologic Relevance of Convulsive Geologic Events. Geological Society of America Special Papers, 229, 1-6.

[83] Müller, A.M.K. (1981) Interdisziplinäre Forschung als Geschichtliche Herausforderung. Pressestelle der Universität Humburg, Hamburg, 37-45.

[84] Arabian Geophysical and Surveying Company (ARGAS) (1968) Seismic Report El Lisan-Ghor Safi: ARGAS unpubl. Report. Jordan Natural Resources Authority, Amman. 
Scientific Research Publishing (SCIRP) is one of the largest Open Access journal publishers. It is currently publishing more than 200 open access, online, peer-reviewed journals covering a wide range of academic disciplines. SCIRP serves the worldwide academic communities and contributes to the progress and application of science with its publication.

Other selected journals from SCIRP are listed as below. Submit your manuscript to us via either submit@scirp.org or Online Submission Portal.
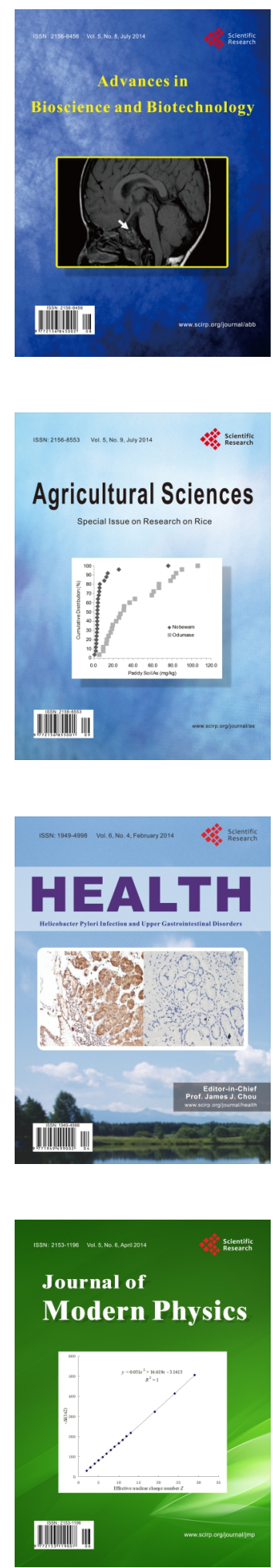
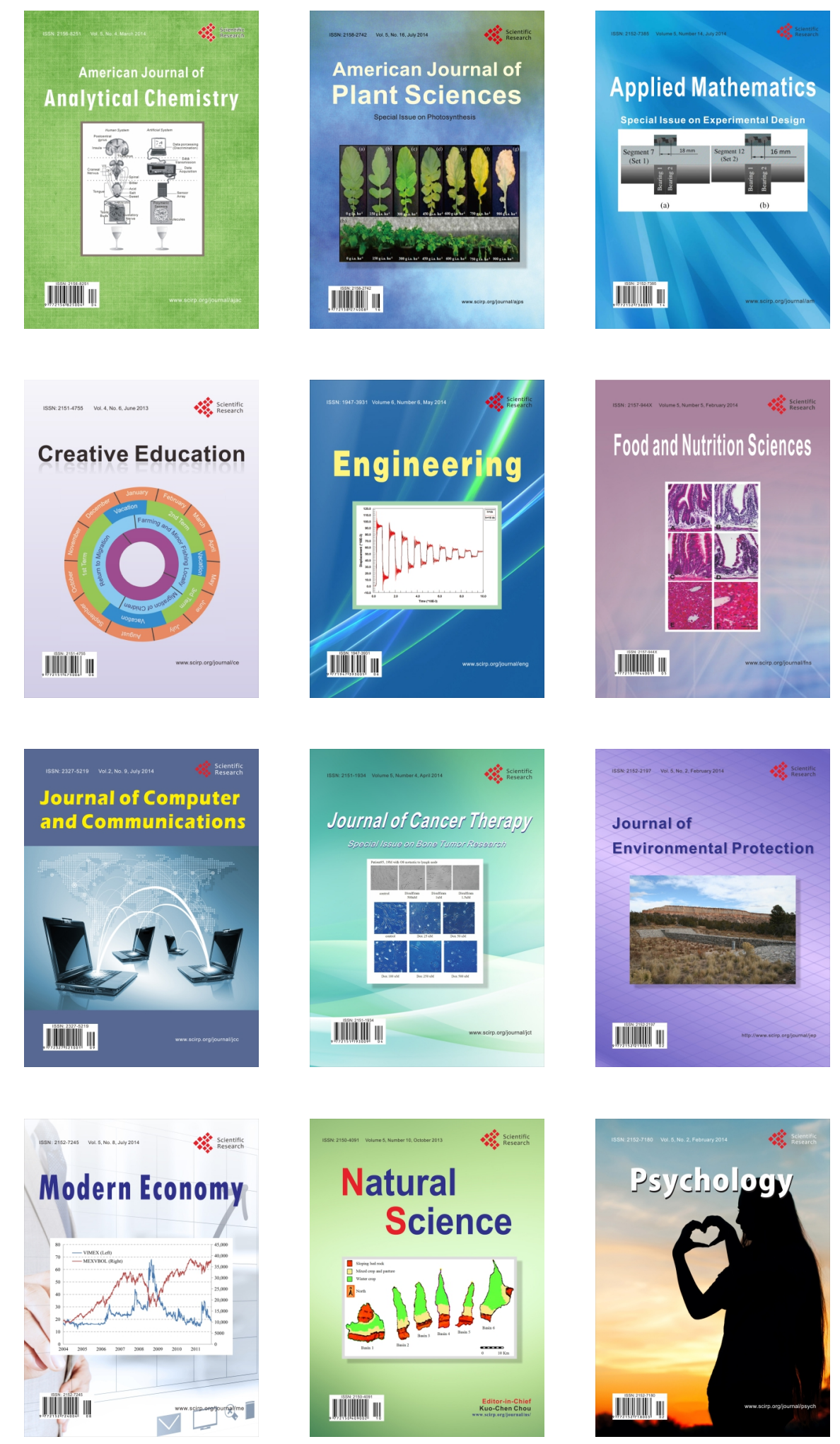